\title{
Economic Design of Hybrid Pico-Hydraulic/Photovoltaic Generation System: A Case Study in Egypt
}

\author{
Fathalla F. Selim ${ }^{1, *\left(\mathbb{D}, \text { Almoataz Abdelaziz }^{2}(\mathbb{1}) \text { and Ibrahim B. M. Taha }\right.}{ }^{3}$ \\ 1 Department of Electrical Engineering, Faculty of Engineering, Kafrelshiekh University, \\ Kafrelshiekh P.O. Box 33516, Egypt \\ 2 Faculty of Engineering and Technology, Future University in Egypt, \\ Cairo P.O. Box 11835, Egypt; almoatazabdelaziz@hotmail.com \\ 3 Department of Electrical Engineering, College of Engineering, Taif University, \\ P.O. Box 11099, Taif 21944, Saudi Arabia; i.taha@tu.edu.sa \\ * Correspondence: hegaz2009@yahoo.com
}

Citation: Selim, F.F.; Abdelaziz, A.; Taha, I.B.M. Economic Design of Hybrid Pico-Hydraulic/Photovoltaic Generation System: A Case Study in Egypt. Electronics 2021, 10, 2947. https://doi.org/10.3390/ electronics10232947

Academic Editor: Albert Smalcerz

Received: 23 October 2021

Accepted: 21 November 2021

Published: 26 November 2021

Publisher's Note: MDPI stays neutral with regard to jurisdictional claims in published maps and institutional affiliations.

Copyright: (c) 2021 by the authors. Licensee MDPI, Basel, Switzerland. This article is an open access article distributed under the terms and conditions of the Creative Commons Attribution (CC BY) license (https:/ / creativecommons.org/licenses/by/ $4.0 /)$.

\begin{abstract}
Clean and renewable energy sources are the preferable power system generations for the overall world. This research aims to present a very highly integrated, economic, professional, and simple construction, clean and natural resources usage of the renewable hybrid generation system. This research performs analysis, systematic representation, evaluation, and design of the hybrid proposed system — pico-hydraulic from home usage water and photovoltaic (PV) — to generate an optimal renewable generation system using a new professional control system. Applying this proposed technique in Egypt shows that the hybrid system successfully overcame Egypt's energy crisis. Renewable energy will rise to $8.782 \%$ by increasing $7.323 \%(14,408.83 \mathrm{GWh} / \mathrm{Y})$. Besides, this system increases the power supply reliability; it gives an additional emergency supply and reduces the exhausts from other generation stations (e.g., $\mathrm{CO}_{2}$ ). The saving from this hybrid system is very effective for; the residential sector (subscribes), which will be ranged from 9599.298 million $\mathrm{E} £ / 10 Y$ s up to $86,393.68$ million $\mathrm{E} £ / 10 Y$ s that equals 5399.6 million $\$$, government to use this extra generation energy to reduce the maximum loads from various stations. A practical model has been presented with results to verify the high efficiency of the proposed system that illustrates the effective performance of the used hybrid system.
\end{abstract}

Keywords: renewable energy; hybrid proposed generation system; exhausts; residential; economic strip

\section{Introduction}

One of the main incentives for economic development is enhancing the electric energy sector, as it plays a significant role in present-day civilization [1]. Due to population growth, human comfort level boosting, and industrialization development, electricity demand is increasing rapidly globally with an annual growth rate of $4 \%$ [2]. Therefore, most researchers are interested in how to save or generate electrical power.

\subsection{Saved Power Literature Overview}

The saving in power for all consumed sectors, especially the buildings considered one of the largest energy sectors, about 30-32\%, from the total energy productions. For example, the retail sector may reach up to $80 \%$ of the energy used [3,4].

These saved methodologies studies apply to traditional homes and smart homes. Generally, smart home technologies have reached a good state of maturity, but these are not found in all countries [5]. Paper [6] refers to some of the smart home projects: the Computer-aided design software for smart home devices (based on cloud computing service project) helps the designer to select the smart home device and build a smart living space (visual stimulation). In addition, in Refs. [6,7], another project called energy saving 
depends on using sensors to minimize domestic energy waste according to human habits. One of the earliest projects is Mozer's adaptive control of the US's home environment (ACHE) system. ACHE can use adaptive sensors to control: temperature, heating, and lighting. Authors in [8] introduce energy usage scheduling and management under electric utility to solve the energy management problem and reduce bill cost, peak-to-average ratio, and carbon emission. The model presented in [9] interests saving lighting power by applying an appropriate lighting design system. The saving system introduced in [10] reviews more than 23 power saved researches with different methods/strategies. Other saving researches [11-14] present the various controlled lighting system to give the required illuminance according to the human occupancy/reference to the place activity or by the vehicles traffic density in the street as in [12], illumination sensors as in [13,14] uses sensortriggered control strategies. Due to the importance of commercial buildings, paper [15] gives a hybrid system to save consumed power at high levels.

\subsection{Related Works Overview}

Most of the world's energy is derived from fossil fuels which cannot supply all the required load demand-depleted and limited- and contributes to high exhausts (traditional generation systems give nearly $75 \%$ of total $\mathrm{CO} 2$ emission in the world) [16].

There are many works of the literature on RE generation systems which can conclude generation types (PV, Wind ... etc.), enhancement production methodologies, etc.

In recent years, many research studies have tried to reach the optimal generation/ operation from the very important type (RE)(samples):

- $\quad$ The RE can reduce the exhausts to provide a clean environment through studies [17].

- The optimal production with PV generation requires various methodologies and techniques [18,19].

- Other researchers execute the various combined methods (Hybrid) to reach the optimal production, such as [16,20-22], which are very effective in reaching optimal production with the economy.

From the above sections;

- There is a need to produce additional electrical power from RE to satisfy the unsupplied loads throughout the world,

- The generation of Hybrid RE is a very effective electrical production system w.r.t traditional and single method,

- Most research scope about the advanced methodologies that may be cannot be applied in practical especially the developing countries and with popular human houses.

Therefore, the key contribution of this paper is the development of a comprehensive and actual optimal for generating power from Hybrid Pico-hydraulic/Photovoltaic by effective/simple methodology. This study gives an applied model in the popular home using RE of solar energy and water by the lowest cost and high saving money method as explained in the case study section.

An applicable model is verified in Egypt -as a case study-to show how this proposed technique can effectively increase the RE generation for the government and save money for the consumers.

\section{Egypt Renewable Energy Scenario}

In Egypt, about $95 \%$ of the population is served by the electricity grid. The current available capacity is larger than the peak load by only $3 \%$ "lower than the internationally advisable margin of $15 \% "$. Thermal plants supply most of the energy, and the remaining demands are supplied by large hydro plants with very low percentages by independent power producers (e.g., wind) [23]. According to [24], 91.43\% of total power production is from thermal plants (95.91\% from natural gases and 4.09\% from heavy oil), hydro plants give $7.27 \%$, wind and solar give $1.91 \%$. According to the duration of the sun's brightness, PV systems be economical or not for smart houses (proposed technique). Some 
information about Egypt's renewable energy with solar energy will be introduced in the following paragraphs:

The duration of the sun's brightness is high throughout Egypt, starting from a low level of $3300 \mathrm{~h} / \mathrm{Y}$ along the northern part of places such as Alexandria to reach the highest level of more than $4000 \mathrm{~h} / \mathrm{Y}$ in most parts of the country $[25,26]$. The average daily brightness of the sun ranges between 9.3-10.8 $\mathrm{h} / \mathrm{D}$ [27]. In the north, it ranges from $6-8 \mathrm{~h} / \mathrm{D}$, while it is between $8-10 \mathrm{~h} / \mathrm{D}$ in the south. The number of hours of sunshine increases in summer to a maximum of $12 \mathrm{~h} / \mathrm{D}$ in June and July [28,29].

Although Egypt is vast and has abundant solar energy resources, the numbers of meteorological stations are few. Therefore, many methodologies are done to solve this problem [30,31].

There are updated Egyptian studies that focus on how great benefits of PV system in Egypt are to give the maximum output green generation [32], and discuss the quality effects of PV generation outputs (I, V) on the low voltage grid of Electronics Research Institute Egypt [33]. The hybrid systems for various generation and applications types are applied to give the most economic and efficient solution, such as the application of hybrid wind/P.V. energy system for a remote area in Egypt [34] and supply the required loads without any defaults of the grid "DGs" while keeping the distribution network within minimum pollution [35].

\section{Methodology}

The methodology has been selected and developed based on the aim of this case study. The methodology has been based on; designing hydraulic and PV systems, the mathematical calculations of the required power to satisfy decided power, and limiting the home consumer bill to the economic range. It is based on estimating the required power needed from the RE hybrid system to maintain the monthly residential home on the economic strip. This economic strip will be decided from the tariff of the ministry of Egypt electricity. The comparison shall explain that the hybrid system can give the required power by an easy and simple method with minimal cost w.r.t the traditional power supplied by the government. The proposed, tested model will verify the methodology, and this model builds on Figures 1-3. These Figures investigate how can generate the required power from a hybrid system; Figure 1 explains the integrated generation system flowchart (verify the supply power/voltage maintained at a certain level under any circumstances), Figure 2 display the structure of hybrid system components and the perfect places of them, and Figure 3 indicates the logic circuit to fix the power/voltage at the required level. 


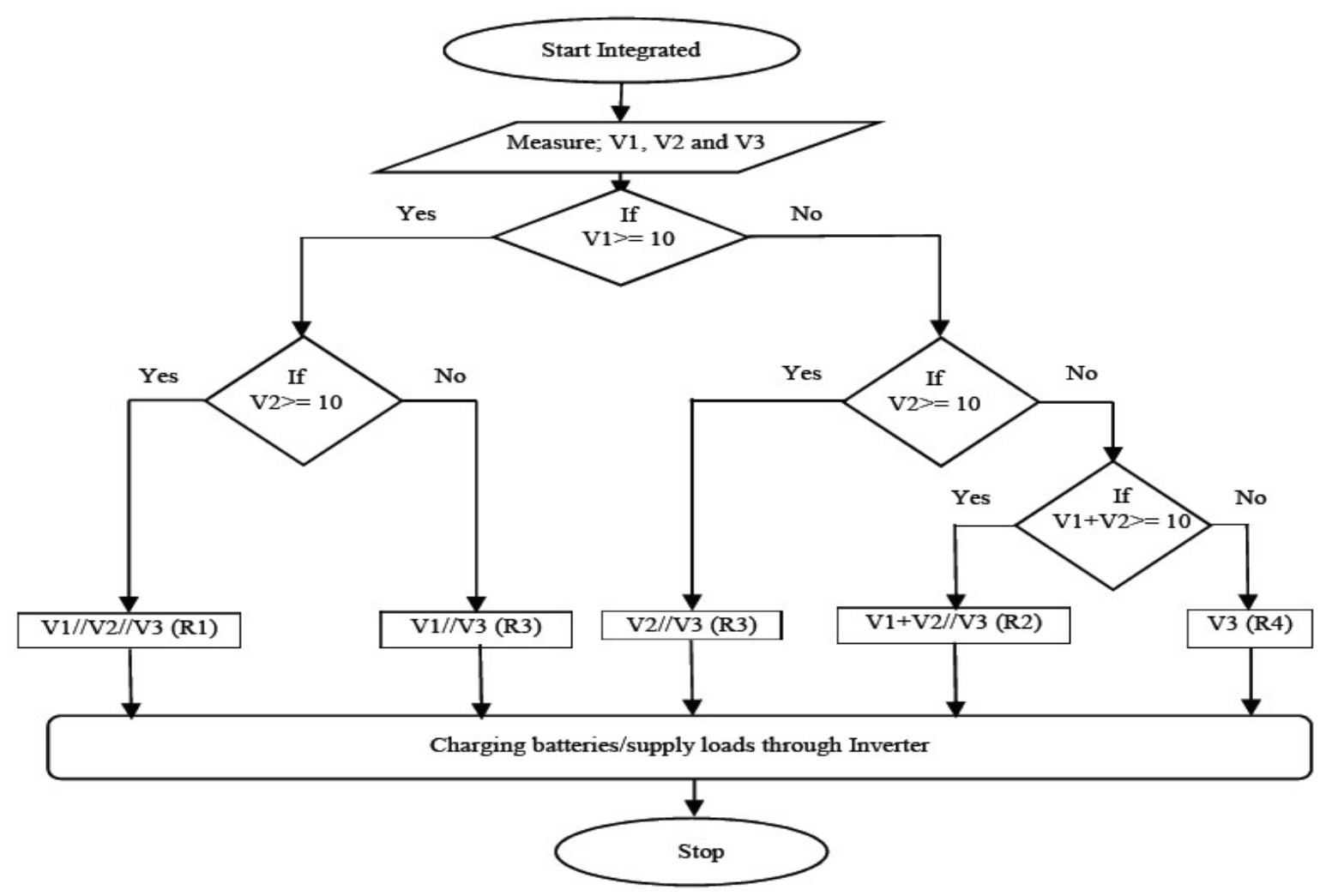

Figure 1. Integrated generation system flowchart.

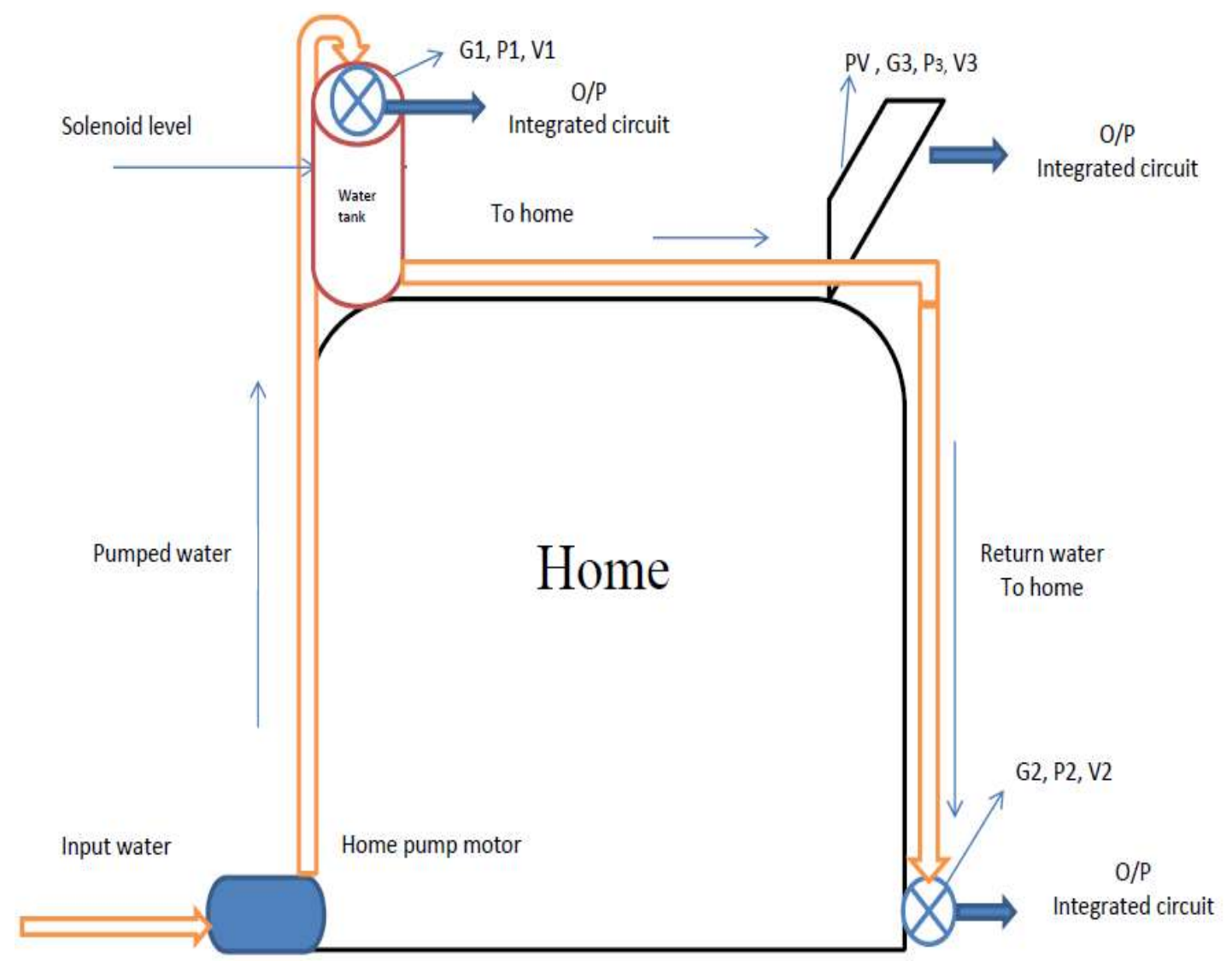

Figure 2. House generation systems places. 


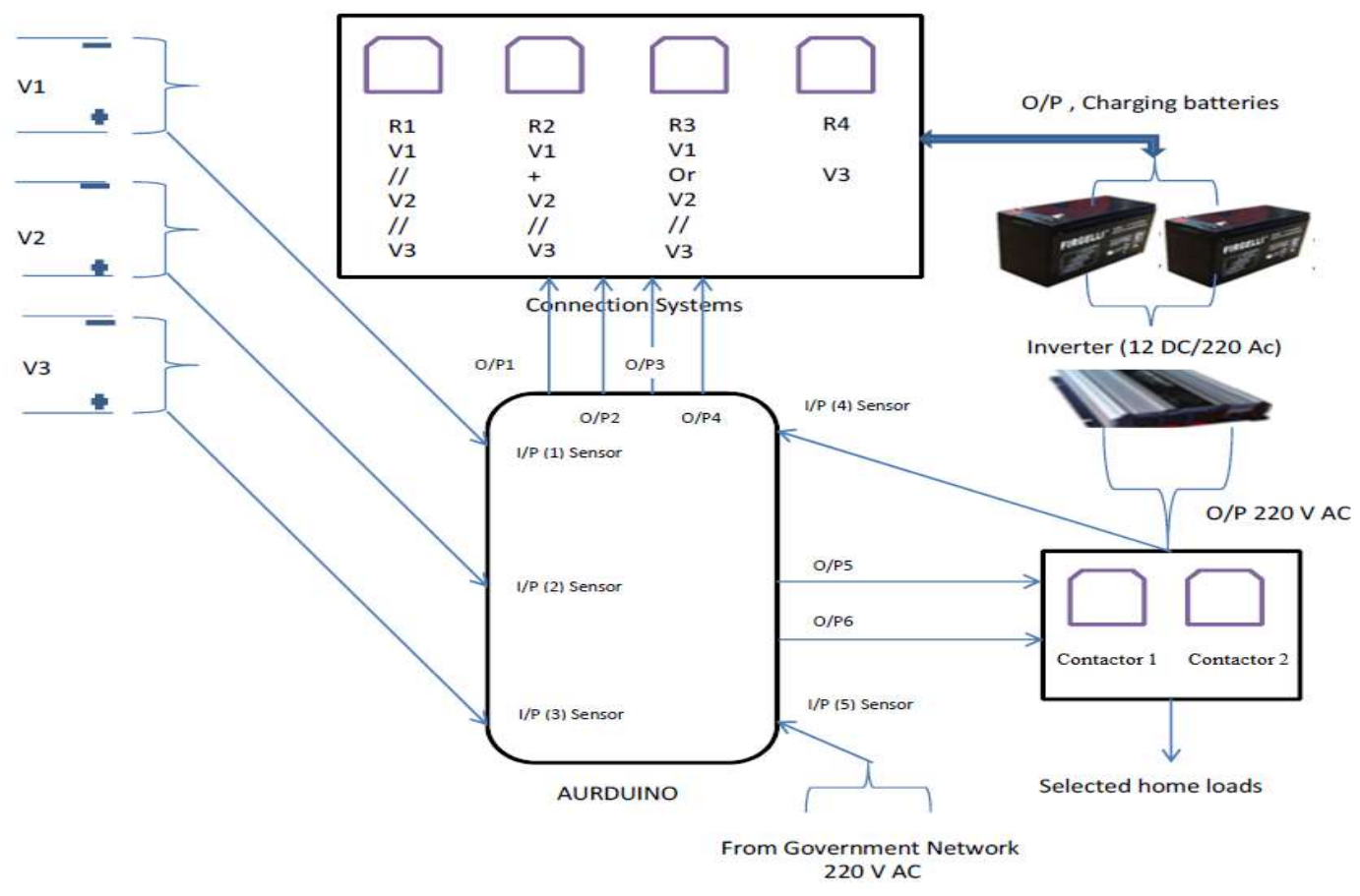

Figure 3. The integrated generated power model.

\section{The Hydraulic Electrical Power Generation System}

Energy is a critical factor in developing countries; one of these is hydraulic (hydropower) renewable energy, which has the largest renewable resource and multi-advantages w.r.t other generated electrical sources. It plays an essential role in many world regions, with more than 150 countries generating hydroelectric power. For example, it provides about 96 percent of the renewable energy in the United States [36-39]. Therefore, it has added attention to optimize the operation [40] and generate compensatory of other generation types [41,42]. In the hydraulic power stations (Hydropower on a small scale), the electrical energy can be generated by water kinetic energy, which can activate the mechanical turbine's energy [43,44]. Table 1 indicates the hydraulic power generation plant (categories) [45].

Table 1. The hydraulic power plant categories [42,45,46].

\begin{tabular}{ccc}
\hline Category & Capacity & Application \\
\hline Large & $50-1000 \mathrm{MW}$ & Large cities \\
Small & $1-50 \mathrm{MW}$ & Small cities to towers \\
Mini & $100-1000 \mathrm{~kW}$ & Towers \\
Micro & $<100 \mathrm{~kW}$ & Rural community \\
Pico & $<5 \mathrm{~kW}$ & Individual home \\
\hline
\end{tabular}

A Pico-hydro system might produce just $2 \mathrm{~kW}$, whereas a large utility-scale hydro system could easily produce hundreds of Megawatts. So that, a $2 \mathrm{~kW}$ hydropower system could satisfy the annual electrical energy needs of two average UK homes, whereas a utilityscale 200 MW system could supply 200,000 average UK homes [47]. Many researchers are interested in hydraulic generation energy for very low values, as in [48], which uses the kinetic energy inside the home pipelines to produce about $10 \mathrm{~W}$.

The work suggested in [49] provides updated information on the challenges and innovation trends and emerging hydropower technologies. 


\subsection{Electric Power Computation}

Hydropower on a small scale is one of the most cost-effective energy technologies to be considered for rural electrification in less developed countries. Small hydro technology is extremely robust and is one of the most environmentally benign energy technologies available [37]. The capacity of the hydraulic unit-generated power- and, accordingly, turbine type depends upon some factors; the volume of water discharge, the distance head (water pressure), and the rotational speed of the generator. In general, the theoretical mechanical horsepower can be calculated by $[36,37,44]$ :

$$
\mathrm{P}_{\mathrm{m}}=\frac{\mathrm{Q} \times \mathrm{H}}{8.8}
$$

where;

$\mathrm{P}_{\mathrm{m}}$ is the theoretical mechanical horsepower

$\mathrm{Q}$ is the flow rate in cubic feet per second

$\mathrm{H}$ is the head in feet.

According to [50], water in motion possesses three forms of energy; kinetic energy due to its velocity, pressure energy due to its pressure, and potential energy due to its height:

$$
\begin{gathered}
\text { Kinetic energy }=\frac{\mathrm{V}^{2}}{2} \\
\text { Pressure energy }=\frac{\mathrm{P}}{] \rho} \\
\text { Potential energy }=\mathrm{g} \times \mathrm{H}
\end{gathered}
$$

where:

$\mathrm{V}$ is the velocity of flow, $\mathrm{m} / \mathrm{s}$

$P$ is the pressure, $N / \mathrm{m}^{2}$

$\rho$ is the density of water, $\mathrm{kg} / \mathrm{m}^{3}$

$\mathrm{H}$ is the height of the level of water above some datum level, $\mathrm{m}$

The generated electrical power can be calculated by [39,40,46,50-53]:

$$
\begin{gathered}
\mathrm{P}_{\mathrm{t}}=\mathrm{Q} \times \rho \times \mathrm{g} \times \mathrm{H}_{\mathrm{n}} \times \eta_{\mathrm{t}} \\
\mathrm{H}_{\mathrm{n}}=\mathrm{H}_{\mathrm{g}}-\mathrm{H}_{\mathrm{lo}} \\
\mathrm{Q}=\frac{\mathrm{P}_{\mathrm{t}}}{\rho \times \mathrm{g} \times \mathrm{H}_{\mathrm{n}} \times \eta_{\mathrm{t}}} \\
\mathrm{P}_{\mathrm{op}}=\mathrm{P}_{\mathrm{t}} \times \eta_{\mathrm{g}}
\end{gathered}
$$

where (as shown in Figure 4):

$\mathrm{P}_{\mathrm{t}}$ is the output from the turbine, $\mathrm{W}$

$\mathrm{Q}$ is the flow rate in the pipe, $\mathrm{m}^{3} / \mathrm{s}$

$\mathrm{G}$ is the acceleration of gravity (for water $=9.81$ ), $\mathrm{m} / \mathrm{s}^{2}$

$\mathrm{H}_{\mathrm{n}}$ is the net height, $\mathrm{m}$

$\mathrm{H}_{\mathrm{g}}$ is the gross vertical head, $\mathrm{m}$

$\mathrm{H}_{\mathrm{lo}}$ is the head loss, $\mathrm{m}$

$\eta_{t}$ is the turbine efficiency

$\mathrm{P}_{\mathrm{op}}$ is the net output from the generator, $\mathrm{W}$

$\eta_{\mathrm{g}}$ is generator efficiency 
Input Water Level

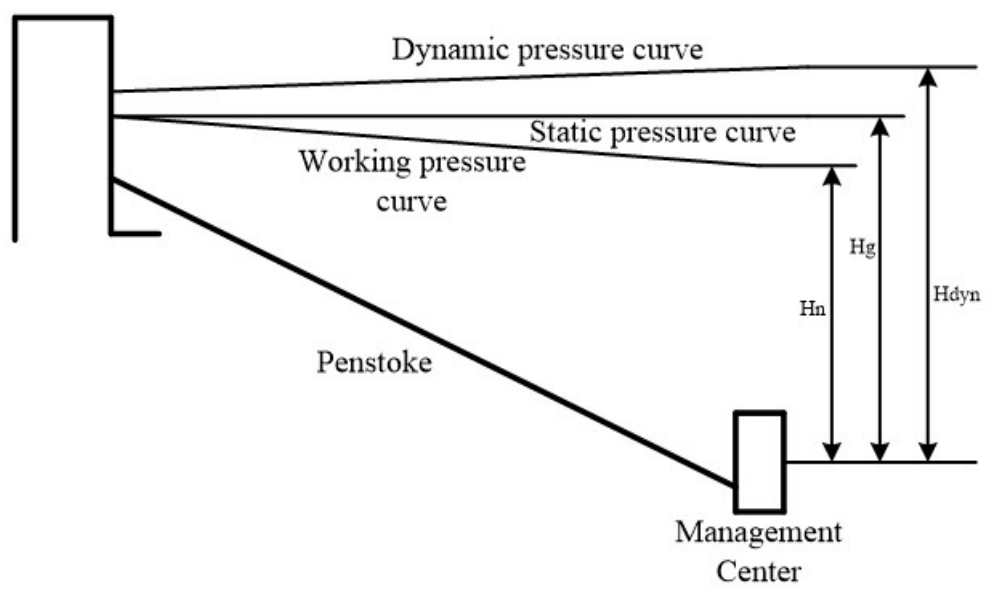

Figure 4. Principle scheme of hydroelectric power system [39].

According to [54], the overall efficiency factor $\left(\eta_{g} \times \eta_{t}\right)$ ranges from 0.5 to 0.7 , depending on the capacity and type of system. The specific turbine speed can be calculated by [39]:

$$
\mathrm{N}_{\mathrm{s}}=\frac{\mathrm{N}_{\mathrm{t}} \times \sqrt{\mathrm{Q}}}{\mathrm{H}_{\mathrm{n}}^{3 / 4}}
$$

where:

$\mathrm{N}_{\mathrm{s}}$ is the specific speed of the turbine, rpm

$\mathrm{N}_{\mathrm{t}}$ is turbine's rotation speed, $\mathrm{rpm}$

According to [55], the efficiency factors of power stations from the Ministry of Electricity and Energy's annual reports range between $84.9 \%$ and $85.6 \%$ at the "Aswan Hydraulic station". The velocity head (V) equals [39,53]:

$$
\mathrm{V}=\frac{\mathrm{Q}}{\pi \mathrm{r}^{2}}
$$

From the above equations, the production of energy depends mainly on parameters [37,45]: The amount of water available " $\mathrm{Q}$ ", water loss due to flood spill and friction, the difference in head between upstream intake and downstream outlet, and the efficiency in energy conversion of electromechanical equipment.

\subsection{Hydraulic Turbine Classifications}

There are two main turbine types: Impulse (e.g., Pelton wheel, Turgo-impulse wheel, Girad turbine) and Reaction (e.g., Fourneyron, Thomson, Francis, etc.). These turbines have their construction, benefits, applications, and appropriate commercial turbine names [50]. In addition, the hydraulic turbine can be classified according to [50-52]: Head and quantity of water, Originator name, Nature of bladed working, The direction of water flow, Turbine shaft axis, and Specific speed. For example, Deriaz turbines can be used up to $300 \mathrm{~m}$. Table 2 gives the recommended turbine types related to water heads $[41,50]$.

\subsection{Pumped Storage}

Pumped storage plants are used during off-peak hours to pump water from a lower reservoir into an upper reservoir "storage water" $[5,37,56,57]$. In the present study, the home water pump is used as pumped storage, but the kinetic water energy will be used in two ways, as explained in the following sections. Figure 5 explains the pumped storage scheme [56]. 
Table 2. Recommended turbine types related to water head [50].

\begin{tabular}{ccc}
\hline Type of Turbine & Range of Head & Specific Speed in Metric Units \\
\hline Pelton (1 nozzle) & $200 \mathrm{~m}$ & $10-20$ \\
Pelton (2 nozzle) & to & $20-40$ \\
Pelton (4 nozzle) & $2000 \mathrm{~m}$ & $40-50$ \\
\hline Turgo impulse turbine & as above & $50-100$ \\
\hline Francis (low speed) & $15 \mathrm{~m}$ & $80-120$ \\
Francis (medium speed) & to & $120-220$ \\
Francis (high speed) & $300 \mathrm{~m}$ & $220-350$ \\
Francis (express) & & $350-420$ \\
\hline Propeller & $5-30 \mathrm{~m}$ & $310-1000$ \\
\hline
\end{tabular}

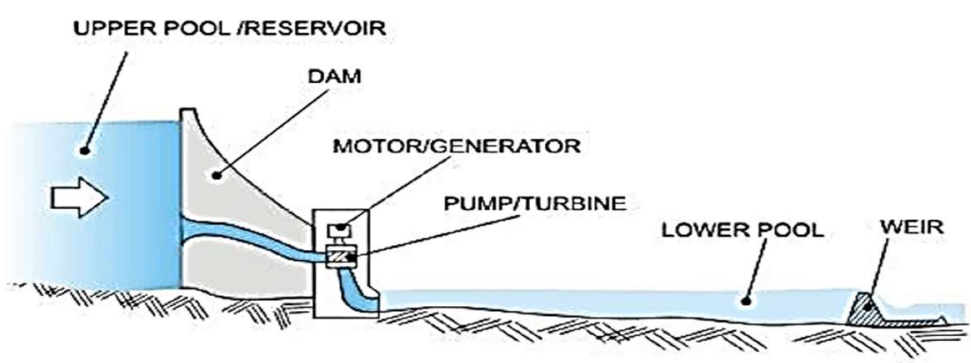

Figure 5. Pumped storage scheme [56].

\section{PV System}

PV system is a very important method for generating power, as referred to in most research for RE resources. This study uses a PV system with normal operation, and the PV required power will be decided through the next sections. This PV generation system will give the supplemental w.r.t hydraulic electrical power. The next sections will show how this proposed low PV generation will increase the sharing of RE sources in Egypt.

\section{Proposed System}

The proposed integration system is a multi-generation system that contains two cooperation systems; Pico-hydro generation, similar to consumed water distributed in houses $[48,58]$ with solar generation system. This proposal will be applied by deciding the required power value, which can save any supplied power system in saved cost levels. Thus, there are two needed values to reach this goal, the first from Pico-hydro generation and the other from PV generation. In the case of, the study applies in the house to maintain its monthly electrical bill to saved level (economic-strip). Therefore, the proposal has the following tasks:

- Decides the powers needed from PV and hydraulic systems (hybrid system) to limit the consumed monthly house bill to certain economical money paid,

- Illustrates the steps, with the mathematical controlled equations and procedures, to verify this goal, and

- Confirms the proposed technique with the actual model.

Due to the present highly consumed home energy, the electrical strip "residential/commercial" can easily change from economical to investment (expensive). Therefore, with simple and professional techniques (Figures 1-3), the proposed methodology will overcome this challenge to limit the home strip "segment" to the economic one. The following section illustrates the proposed integrated system: the mathematical calculations, the various components, the complete design, the practical model with its application, and the cost analysis. 


\subsection{Pico-Hydro Generation System}

The study determines the feasibility and achievability of the proposed Pico-hydro system through the following:

\subsubsection{Power Determination}

In this study, there are some assumptions:

- The daily consumed power for each family home person is denoted by $\left(\mathrm{P}_{\mathrm{p}}, \mathrm{W} /\right.$ day $)$,

- The number of family persons is (n),

- The actual total family persons daily consumed power is $\left(\mathrm{P}_{\mathrm{T}}=\mathrm{n} * \mathrm{P}_{\mathrm{p}}, \mathrm{W} /\right.$ day),

- The consumed water/person is denoted by $\left(\mathrm{Q}_{\mathrm{p}}, \mathrm{L} /\right.$ day $)$,

- The total consumed water for all family persons is $\left(\mathrm{Q}_{\mathrm{T}}=\mathrm{n} * \mathrm{Q}_{\mathrm{p}}, \mathrm{L} /\right.$ day), and

- The total consumed power for all family persons must be limited to economic value denoted by $\left(\mathrm{P}_{\mathrm{ec}}, \mathrm{W} /\right.$ day $)$.

From the above assumptions and the hybrid system data: the required generation value for the bill to be economical is:

$$
\mathrm{P}_{\text {req }}=\mathrm{P}_{\mathrm{T}}-\mathrm{P}_{\mathrm{ec}}
$$

Suppose that; $\mathrm{Q}$ " $=\mathrm{Q}_{\mathrm{T}}$ ", $\rho$, $\mathrm{g}$ and $\mathrm{P}_{\text {req }}$ are known, and others will be decided. There are two-generation units in the proposed systems: One of them is fixed in the outlet of the pumped pipe motor "inside the water home tank", which depends on the motor pump water pressure without any friction or loss $\left(\mathrm{P}_{1}\right)$, and the other is fixed in the way pipe supply water from the tank to daily home consumed waters "laundry, cook and bathe", it has kinetic energy that depends on the head of fall water $\left(\mathrm{H}_{n}\right)$.

From [58], the relation between the head $\left(\mathrm{H}_{\mathrm{n}}\right), \mathrm{m}^{\prime \prime}$ and the pressure $\left(\mathrm{P}_{\mathrm{w}}, \mathrm{psi}\right)$ is:

$$
\mathrm{H}_{\mathrm{n}}=0.704 \times \mathrm{P}_{\mathrm{w}}
$$

Therefore, the power generation from the first unit " $\mathrm{P}_{1}$ " can be calculated by:

$$
\mathrm{P}_{1}=0.704 \times \mathrm{P}_{\mathrm{w}} \times \mathrm{Q}_{\mathrm{T}} \times \mathrm{g} \times \rho \times \eta_{\mathrm{t}} \times \eta_{\mathrm{g}}
$$

However, the second "water return way" has generation value " $\mathrm{P}_{2}$ ", it can be calculated by:

$$
\mathrm{P}_{2}=\mathrm{Q}_{\mathrm{T}} \times \mathrm{H}_{\mathrm{n}} \times \mathrm{g} \times \rho \times \eta_{\mathrm{t}} \times \eta_{\mathrm{g}}
$$

\subsubsection{The Used Equation Parameters}

There are important parameters, which can be calculated with high accuracy: The decided turbine and generators' efficiencies, which are based on the used percentages in [58], as shown in Figure 4, the gross head $\left(\mathrm{H}_{\mathrm{g}}\right)$ and the head loss $\left(\mathrm{H}_{\mathrm{lo}}\right)$ in the water tank (Figure 4) depend on; type, diameter, length of the pipe tank, and the number of bends or elbows, the water flow rate $(\mathrm{Q})$ can be calculated by the same method (bucket method) in [58], and turbine type; the used turbine type depends on its place and generation power limits. In this study, the used turbine is impulse type. According to many concerns presented in [58] permanent magnet DC generator is used. The calculated quantity of pumped water by motor [59]:

$$
\text { whp }=\frac{\mathrm{gpm} \times \mathrm{TDH}(\mathrm{ft})}{3960}
$$


Due to the pumped water (motor) does not give the full efficiency [45], equation (15) will be divided by 0.8 [59] for small electric motors", Equation (15) will be:

$$
\text { whp }=\frac{\mathrm{gpm} \times \mathrm{TDH}(\mathrm{ft})}{3960 \times 0.8}
$$

where:

$\mathrm{TDH}$ is the total dynamic head in feet

Gpm is the pumping rate in gallons per minute, and

Whp is the water horsepower.

\subsection{Solar Energy System}

Due to the decrease in traditional energy resources, the world energy generated systems are interested in renewable energy resources to ensure energy security and strengthen/maintain the environment without polluting "green energy" [60,61]. Some of the most interesting recent researches and studies are solar energy (photovoltaic "PV"), which is an environmentally friendly power generation source [62-64]. Many researchers have paid attention to getting the maximum generation energy from PV/PVT/PV-PVT$\mathrm{CR} / \mathrm{CPV}$ with other supplementary systems [65-70] to give the required residential loads depending on the net-metered load data and system install data [71]. The generation with this PV system be denoted by $\left(\mathrm{P}_{\mathrm{s}}\right)$.

This proposed hybrid system has standard generation powers in the market and purchasing power $\left(\mathrm{P}_{2}\right)$ according to the following equation:

$$
\mathrm{P}_{\text {req }}=\mathrm{P}_{1}+\mathrm{P}_{2}+\mathrm{P}_{\mathrm{s}}
$$

Therefore, if the Pic-hydro generation power $\left(\mathrm{P}_{1}+\mathrm{P}_{2}\right)$ is sufficient to limit the segment to its economic value; there is no need to add solar generation power " $\left(\mathrm{P}_{\mathrm{s}}\right)$.

\subsection{The Proposed Integrated System}

The proposed system can be explained through:

- The flowchart in Figure 1 shows the proposed technique integrated procedures (programming), which indicates the maintained supply outputs voltages and power to charge the battery/selected loads under various circumstances,

- The proposed pico-hydraulic and PV model is displayed in Figure 2; the compound system contains two pico-hydraulic and one PV generation unit to supply the required power $\left(\mathrm{P}_{\text {req }}\right)$, and

- The integrated system shown in Figure 3 contains three-generation outputs units (P1, $\mathrm{P} 2$, and P3/Ps), the Arduino program circuits, different relays operations (R1, R2, $\mathrm{R} 3$, and R4), charging circuit to storage energy battery/s, inverter to convert DC/AC voltage and selected loads contractors, this system is responsible for maintaining the supply voltage/power to batteries/loads under different cases.

This study investigates a very effective, simple, economic, and handled model. Therefore, the main contributions of this study are:

- Explaining the benefits by using the daily natural resources for generating electrical energy;

- Maintaining the supply voltage/power from the proposed circuit by a new simple and professional control system for certain values (a proposed technique in Figures 1 and 3);

- $\quad$ Applying the proposed integrated circuit (Figure 2 and Figure 13);

- Limiting the consumed electrical energy bill to a certain acceptable economic strip level by hybrid generation system;

- Executing high savings in energy and money and helping the environment to get rid of toxic exhausts such as $\mathrm{CO}_{2}$; and 
- Verifying the proposed system by actual case study in Egypt.

7. Design the Proposed System with Actual Case Study

In this paper, the proposed methodology will be implemented by an actual case study in Egypt. According to Figure 6 ([72], last report 2017-2018),

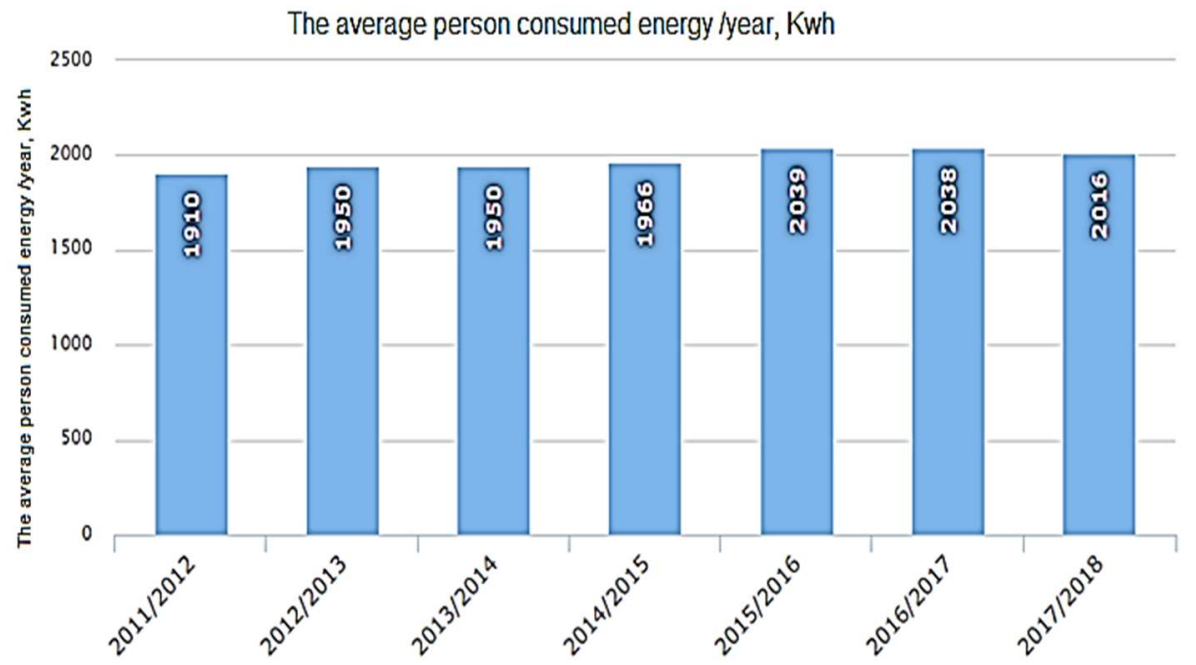

Figure 6. The average person consumed energy/year, kWh [72].

- The annual consumed energy for each Egyptian person is $2016 \mathrm{kWh} / \mathrm{Y}$ "the average person daily consumed energy is $5.5232 \mathrm{kWh}$, Figure 6".

- The economic strip up to $650 \mathrm{kWh} / \mathrm{M}-0.9 \mathrm{E} £ / \mathrm{kWh}(\mathrm{EGP})$ - but investment one from $651 \mathrm{kWh} / \mathrm{M}$ with $1.35 \mathrm{E} £ / \mathrm{kWh}$ - which can be described in Figure 7 [73].

- Based on the report in [74], the average person daily consumed water is 300 Liters.

\begin{tabular}{|c|c|c|}
\hline \multicolumn{3}{|c|}{ Household uses } \\
$\begin{array}{c}\text { Consumption } \\
\text { brackets } \\
\text { (KWh/month) }\end{array}$ & Pt./KWh & $\begin{array}{c}\text { Customer service } \\
\text { EGP/ } \\
\text { customer-month }\end{array}$ \\
\hline $0-50$ & 22.0 & 1 \\
\hline $51-100$ & 30.0 & 2 \\
\hline $0-200$ & 36.0 & 6 \\
\hline $201-350$ & 70.0 & 11 \\
\hline $351-650$ & 90.0 & 15 \\
\hline $651-1000$ & 135.0 & 25 \\
\hline $0-$ more than 1000 & 145.0 & 40 \\
\hline Read by Zero & - & 9 \\
\hline
\end{tabular}

\begin{tabular}{|c|c|c|}
\hline \multicolumn{3}{|c|}{ Commercial uses } \\
\hline $\begin{array}{c}\text { Consumption } \\
\text { brackets } \\
\text { (KWh/month) }\end{array}$ & Pt./KWh & $\begin{array}{c}\text { Customer service } \\
\text { EGP/ } \\
\text { customer-month }\end{array}$ \\
\hline $0-100$ & 55 & 5 \\
\hline $0-250$ & 100 & 15 \\
\hline $0-600$ & 115 & 20 \\
\hline $601-1000$ & 145 & 25 \\
\hline $0-$ more than 1000 & 150 & 40 \\
\hline Read by Zero & - & 9 \\
\hline
\end{tabular}

Figure 7. The electricity sales tariff (2017-2018) [72,73].

These data will help to; decide the limited economical strip, calculate the required generation power from the proposed technique and the actual generation systems (designs and values). Therefore, this proposed system limits the strip to an economic one (saving power and money).

\subsection{Consumed Energy}

Based on the given above data about Egyptian person consumed energy/water and by supposing; the family contains five persons, and the house has two floors, then:

- The total power consumed $\left(\mathrm{P}_{\mathrm{T}}\right)$ is $(5.523 \times 5=27.616 \mathrm{kWh} / \mathrm{D}$ and $828.48 \mathrm{kWh} / \mathrm{M})$, 
- The total consumed water/day is $\left(300 \times 5=1500 \mathrm{~L}\right.$ “ $1.5 \mathrm{~m}^{3}$ "),

- The economic strip is up to $650 \mathrm{kWh} / \mathrm{M}$, which means the monthly needed generation power from the proposed system will be $828.68-650=178.68 \mathrm{kWh} / \mathrm{M}$,

- The proposed technique should generate the remainder value $(27.616-21.66=$ $5.956 \mathrm{kWh} / \mathrm{D})$.

\subsection{The Required Generation}

The required generation power $\left(\mathrm{P}_{\text {req }}\right)$ is $5.956 \mathrm{kWh} / \mathrm{D}(178.68 \mathrm{kWh} / \mathrm{M})$ to limit the strip to the economic level. Therefore, the two proposed generation turbines must give this required power $\left(\mathrm{P}_{\text {req }}\right)$ with or without $\mathrm{PV}$ system according to the following descriptions and submissions:

- $\quad$ The supply pipe diameter is $\frac{3}{4}$ inch with electrical motor power equals $0.75 \mathrm{hp}$, and the motor pump pressure is 5 bar $(5 \times 14.50378=72.5189 \mathrm{Psi})[75,76]$;

- The net head of the water tank to the second pump is $7 \mathrm{~m}$ (G2 in Figure 2);

- The total turbine-generator efficiency is 0.8 and Q will have $0.018,0.026$ and $0.045 \mathrm{~m}^{3} / \mathrm{min}$ (average $\left.(0.018+0.026+0.0450) / 3=0.0296 / 60=0.000493 \mathrm{~m}^{3} / \mathrm{s}\right)[77]$.

The generated power from these turbines are:

7.2.1. The First Generation Turbine $\left(\mathrm{P}_{1}\right)$

- $\quad$ The total high is $7 \mathrm{~m}(1 \mathrm{~m}=3.38 \mathrm{ft})$

- According to [78], one gallon per minute $=5.45099 \mathrm{~m}^{3} /$ day $\left(0.227124 \mathrm{~m}^{3} / \mathrm{h}\right.$ $\left.=3.7854 \times 10^{-3} \mathrm{~m}^{3} / \mathrm{min}\right):$

According to the above data and Equation (16):

$$
0.75=\frac{\mathrm{Q} \times 7 \times 3.38}{3960 \times 0.8}
$$

$\mathrm{Q}=100.422$ g.p. $\mathrm{m}=22.80 \mathrm{~m}^{3} / \mathrm{h}=0.38 \mathrm{~m}^{3} / \mathrm{min}=0.00633 \mathrm{~m}^{3} / \mathrm{s}$

Note; this motor $(0.75 \mathrm{hp})$ will fill the family tank $\left(1.5 \mathrm{~m}^{3}\right)$ through $0.06578 \mathrm{~h}(1.5 / 22.8)$. According to the above data and Equations (13) and (14), $\mathrm{P}_{1}$ has two values:

- $\quad \mathrm{P}_{1}=0.000493 \times 9.81 \times 1000 \times 0.8 \times 0.704 \times 72.5189=197.528 \mathrm{~W}$, or

- $\mathrm{P}_{1}=0.00633 \times 9.81 \times 1000 \times 0.8 \times 0.704 \times 72.5189 \times 0.06578=166.92 \mathrm{~W}$.

7.2.2. The Second Generation Turbine $\left(\mathrm{P}_{2}\right)$

By the same data and equations, $\mathrm{P}_{2}$ has two values:

- $\quad \mathrm{P}_{2}=0.000493 * 9.81 * 1000 * 0.8 * 7=27.083 \mathrm{~W}$, or

- $\mathrm{P}_{2}=0.00633 * 9.81 * 1000 * 0.8 * 7 * 0.06578=22.89 \mathrm{~W}$.

Note that: this hydraulic generation system $\left(\mathrm{P}_{1}\right.$ and $\left.\mathrm{P}_{2}\right)$ does not affect the water flow rate (quantity and pressure).

7.2.3. The Third Generation Turbine $\left(\mathrm{P}_{\mathrm{s}}\right)$

The generations with two pico-hydraulic cannot supply the required power $\left(\mathrm{P}_{\text {req }}\right)$; therefore PV system should supply power $\left(\mathrm{P}_{\text {req }}-\left(\mathrm{P}_{1}+\mathrm{P}_{2}\right)\right)$.

From the above calculations and given data:

- The home water motor will fill the tank by $3.157 \mathrm{~min}$,

- $\quad$ The first generation unit $\left(\mathrm{P}_{1}\right)$ will give from 167 to $198 \mathrm{~W}$ during motor (3.94 min) operations (average $=182.5 \mathrm{~W}$ ),

- The second-generation unit $\left(\mathrm{P}_{2}\right)$ will give from 23 to $27 \mathrm{~W}$ during serviced water homework times (average $=25 \mathrm{w}$ ), and

- The total average generation by pico-hydraulic units are $207.5 \mathrm{~W} / \mathrm{D}$, and the PV system should supply the remaining required power $(5956-207.5=5.7485 \mathrm{~kW} / \mathrm{D})$. 


\section{Summary:}

- The pico-hydraulic proposed system will give a very low percentage $(\approx 4 \%)$ of the required power;

- $\quad$ PV system will supply a huge amount of daily-required power $(\approx 96 \%)$;

- The daily consumed power -5 persons- is $27,616 \mathrm{~W}$, which means that; the average consumed power through one hour $=27,616 / 24=1150.66 \mathrm{~W}$ (pico-hydraulic generation units give $18 \%$ of total consumed home power through one hour);

- The advantages of using the pico-hydraulic generation system are:

1. Supply the emergency loads;

2. High benefits usage of the home waters (supplied and wasted);

3. Give green energy without any exhaust;

4. It is a basic theory to be used in large wide in the high and extended buildings to give more supplied power;

5. Applies for irrigation and sewage pumps systems (very high capacity pumped waters) to give high power.

All the given and calculated data are tabulated in Table 3.

Table 3. The given and calculated data.

\begin{tabular}{|c|c|c|c|}
\hline Item & Value & Item & Value \\
\hline Water motor, hp & 0.75 & $\mathrm{P}_{\text {req }} /$ day, $\mathrm{kW}$ & 5.956 \\
\hline Net head, $H_{n}, m$ & 7 & $\mathrm{P}_{1}+\mathrm{P}_{2} /$ day, $\mathrm{W}$ & 207.5 \\
\hline Q/day, m3 & 1.5 & $\mathrm{P}_{3} /$ day, $\mathrm{W}$ & 5748.5 \\
\hline Person power/day, kW & 5.523 & $\begin{array}{l}\text { \%Pico-hydraulic } \\
\text { shared/day }\end{array}$ & $4 \%$ \\
\hline 5 Persons power/day, Kw & 27.616 & $\begin{array}{l}\text { \%Pico-hydraulic } \\
\text { shared/one hour }\end{array}$ & $18 \%$ \\
\hline
\end{tabular}

Table 4 explains the renewable generation by solar systems related to the total generation of energy in Egypt through 2013-2018 ([74], reports from 2013 to 2018).

Table 4. Total sold energy on all voltages classified according to uses GWh (2013-2018) [72,73].

\begin{tabular}{llllllll}
\hline Generation Type/Years & $\mathbf{2 0 1 2 - 2 0 1 3}$ & $\mathbf{2 0 1 3 - 2 0 1 4}$ & $\mathbf{2 0 1 4 - 2 0 1 5}$ & $\mathbf{2 0 1 5 - 2 0 1 6}$ & $\mathbf{2 0 1 6 - 2 0 1 7}$ & $\mathbf{2 0 1 7 - 2 0 1 8}$ \\
\hline \multirow{2}{*}{ Total, GWh } & & $\mathbf{1 6 4 , 6 2 8}$ & $\mathbf{1 6 8 , 0 5 0}$ & $\mathbf{1 7 4 , 8 7 5}$ & $\mathbf{1 8 6 , 3 2 0}$ & $\mathbf{1 8 9 , 5 5 0}$ & $\mathbf{1 9 6 , 7 6 0}$ \\
\hline \multirow{6}{*}{ Renewable } & Total & 1497 & 1446 & 1558 & 2225.5 & 2780 & 2871 \\
& \% & 0.909 & 0.860 & 0.890 & 1.194 & 1.466 & 1.459 \\
& Solar & 237 & 114 & 0 & 167.5 & 580 & 537 \\
& $\%$ & 0.1439 & 0.067 & 0 & 0.089 & 0.305 & 0.2729 \\
& Wind, & 1260 & 1332 & 1558 & 2058 & 2200 & 2334 \\
\hline \multirow{2}{*}{ Hydraulic } & Gen. & 13,121 & 13,352 & 13,822 & 13,545 & 12,850 & 12,726 \\
& \% & 7.97 & 7.945 & 7.90 & 7.269 & 6.779 & 6.467 \\
\hline
\end{tabular}

From the above discussion and Table 4, it can be noted that:

- Egypt has a high ability to generate energy with solar systems, and

- The generated solar energy is very low related to the total generation energies from various generation stations (does not reach $0.28 \%$ ).

Therefore, this study will remedy raising the percentage share of renewable (lower than $1.5 \%$ ) energy.

\subsection{Costs Analysis}

This section presents the economical dispatch of the proposed technique with hybrid method "pico-hydraulic and PV" related to the traditional government methods: 


\subsubsection{PV System}

The solar energy system (PV) is now one of the most renewable energy sources, all the information about; how the system is used, the components and their prices, etc., can get easily.

According to the above section/subsections and their references:

- $\quad$ The needed power from PV is $5.7485 \mathrm{~kW} / \mathrm{D}$, and

- The minimum times of daily brightness of the sun range 6-8 h/day (average $7 \mathrm{~h}$ ).

Therefore, the required installed $\mathrm{PV}$ rating is one $\mathrm{kW} / \mathrm{h}$ with its other cooperating components.

\subsubsection{Pico-Hydraulic System}

According to Table 3, the DC water generators (pico-hydraulic) rating is $207.5 \mathrm{~W}$. Then, the required components and their prices for the hybrid systems (PV and hydraulic) are shown in Table 5, while Table 6 explains the development of the tariff from 2012/2013-2017/2018 (\% incrimination) [72,73].

Table 5. The required components and their prices " $\$$ " for hybrid system [79-82].

\begin{tabular}{|c|c|c|c|}
\hline Types & Costs, \$/Gen & PV & Hydraulic \\
\hline \multirow[b]{2}{*}{ Solar cell } & Price, $\$ / W$ & & 0.28 \\
\hline & Costs $1000 \mathrm{~W}, \$$ & & 280 \\
\hline \multirow{2}{*}{ DC generator } & Price $(190 \mathrm{~W}), \$$ & 245 & \\
\hline & Price $(20 \mathrm{~W}), \$$ & 25.8 & \\
\hline Arduino & Price, $\$$ & 33 & \\
\hline PCB & Price, $\$$ & 25 & \\
\hline \multirow{2}{*}{ Relays } & Price, $\$$ & 3 & \\
\hline & Price (5), \$ & 15 & \\
\hline \multirow{2}{*}{ Voltage sensors } & Price, $\$$ & 3 & \\
\hline & Price (2), \$ & 6 & \\
\hline Batteries & Price $(1200 \mathrm{~W}), \$$ & 289 & \\
\hline Inverter & Price $(2000 \mathrm{~W}), \$$ & 109 & \\
\hline Accessories and labor & Price, $\$$ & 200 & \\
\hline Total costs, $\$$ & & 1227.8 & \\
\hline
\end{tabular}

Figures 8 and 9 illustrate the tariff incrementations through 5 years for residential and commercial (2013/2014-2017/2018). By using Excel tool to generate the function of each incrementation (e.g., $y=4.7275 \mathrm{x}^{2}+14.723 \mathrm{x}+77.062$ for the first incrementation curve of residential (strip 351-650).

Where:

$\mathrm{y}$ is the percentage incrementation (\%) related to 2013-2014 and $\mathrm{x}$ is the number of year (i.e., 2013-2014 = 1, 2014-2015 = 2...etc.).

\subsubsection{Economic Analysis of Project}

According to [79-83]:

- The guarantee for PV cells is not less than 20 years;

- The guarantee for the inverter is not less than ten years;

- The guarantee for batteries is about two years; and

- The guarantee for the DC generation units is from 8-12 years and other accessories. 
Table 6. Development of Egyptian Ministry of electricity tariff, E£/kWh (2013-2018) (increasing related to $2013-2014$ for each range) $[72,73]$.

\begin{tabular}{|c|c|c|c|c|c|c|c|c|c|c|c|}
\hline \multicolumn{2}{|c|}{ Years } & \multicolumn{2}{|c|}{ 2013-2014 } & \multicolumn{2}{|c|}{ 2014-2015 } & \multicolumn{2}{|c|}{ 2015-2016 } & \multicolumn{2}{|c|}{ 2016-2017 } & \multicolumn{2}{|c|}{ 2017-2018 } \\
\hline Buildings & Strips & Resid. & Comm. & Resid. & Comm. & Resid. & Comm. & Resid. & Comm. & Resid. & Comm. \\
\hline \multirow{4}{*}{ Resid. } & $351-650$ & 0.34 & - & 0.405 & - & 0.55 & - & 0.75 & - & 0.9 & - \\
\hline & $\%$ Increasing & 100 & - & 119.117 & - & 161.76 & - & 220.588 & - & 264.705 & \\
\hline & 651-1000 & 0.6 & - & 0.71 & - & 0.95 & - & 1.25 & - & 1.35 & - \\
\hline & $\%$ Increasing & 100 & - & 118.33 & & 158.33 & - & 208.333 & - & 225 & - \\
\hline \multirow{4}{*}{ Commercial } & $251-600$ & - & 0.59 & - & 0.61 & - & 0.69 & - & 0.96 & - & 1.15 \\
\hline & $\%$ Increasing & - & 100 & - & 103.389 & - & 116.949 & - & 162.711 & - & 194.915 \\
\hline & $601-1000$ & - & 0.78 & - & 0.81 & - & 0.96 & - & 1.35 & - & 1.45 \\
\hline & $\%$ Increasing & - & 100 & - & 103.845 & - & 123.076 & - & 173.076 & - & 185.897 \\
\hline
\end{tabular}

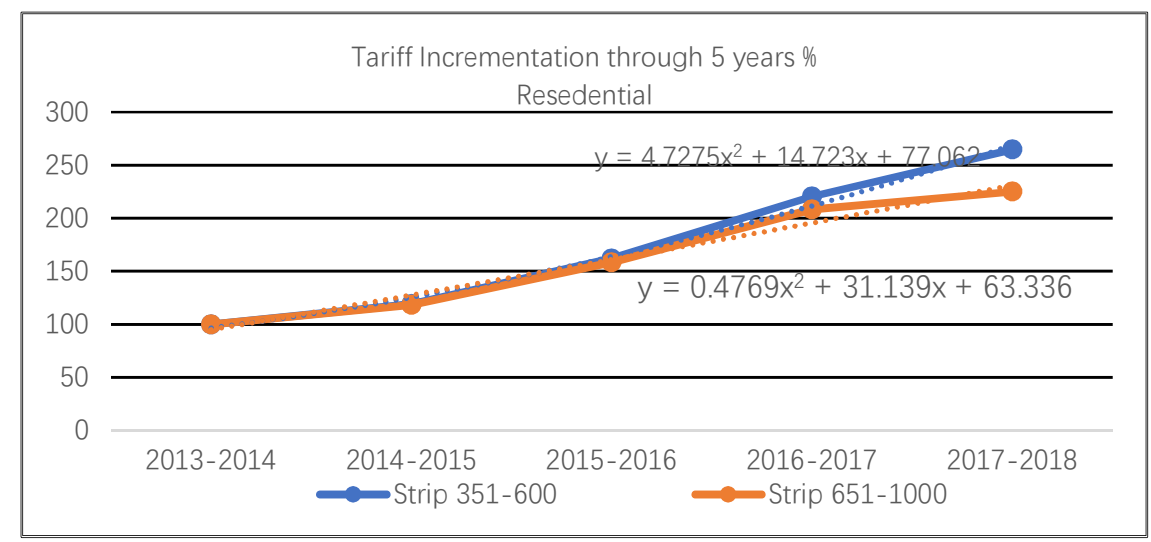

Figure 8. Percentages incrementations in case of residential loads.

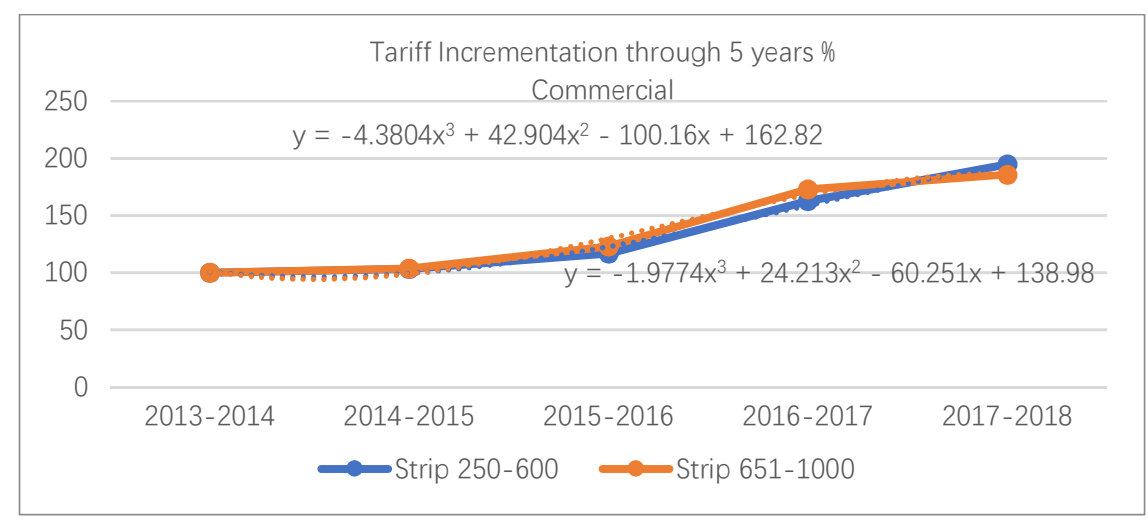

Figure 9. Percentage incrementations in case of commercial loads.

According to the above data about components guarantee and the new control system (Figure 3), the project will still be efficient for ten years. Therefore, the total project costs (adding the replacing batteries four times through ten years, battery guarantee two years only) equal $1227.8+4 \times 289=\$ 2383.8 \approx 38140.8 \mathrm{E} £$, with a rate of change $\$ 1=16 \mathrm{E} £$.

From the above: The yearly project cost is $\$ 238.38 \approx 3814.08 \mathrm{E} £$, and the monthly project cost is $19.865 \approx 317.84 \mathrm{E} £$.

\subsection{Project for Residential Loads}

This section explains the benefits of the proposed hybrid system supplied energy w.r.t the supplied energy with government electricity. 
According to the above sections, the proposed methodology interests the strip from 651-1000 kWh, the investment strip "350-650 is economic strip". From Figure 8, the controlled function for Egyptian tariff incrementations is nearly decided by (Excel facilities functions):

$$
y=0.4769 x^{2}+31.139 x+63.336
$$

Note that:

- Reference [74] has reported up to 2017-2018,

- The required energy from a hybrid system according to the above sections is $178.493 \mathrm{kWh} / \mathrm{M}$ to limit the strip within the economic level,

- This value will be calculated by; using the Egyptian tariff (strip 651-1000) and by the hybrid system to explain its savings,

- By using Equation (18) to decide the percentage incrementations for ten years from 2017-2018, Table 7 and the corresponding Figure 10 show the saving energy and money by using the proposed hybrid system for 10 years project lifetime (basis tariff is 2017-2018),

- $y$ is the percentage incrementations and $x$ is the number of year/s (e.g., $x=5$ for 2017-2018, $x=6$ for 2018-2019...etc.),

- Using Table 6 and Equation (18):

Equation (18) has percentage error $=2.646 \approx 3 \%$ (e.g., for 2017-2018 y $=225$ as actual value (from Table 6), but by Equation (18); $\mathrm{y}=230.95)$, the highest percentage error $=6.14$ $\approx 6 \%$ for: 2016-2017 ( $\mathrm{y}=208.333$, by Equation (18) $\mathrm{y}=195.5224$ ),

- $\quad$ Table 7 values are derived from Equation (19) after multiplying Equation (18) by 0.94 (error of 0.06):

$$
y=\left(0.4769 x^{2}+31.139 x+63.336\right) \times 0.94
$$

Table 7. Incriminations, strip costs, and \% savings for each family ( 5 persons) with proposed methodology through 10 years

\begin{tabular}{|c|c|c|c|c|c|c|c|c|c|c|}
\hline Years & $\begin{array}{l}2017- \\
2018 \\
x=5\end{array}$ & $\begin{array}{l}2018- \\
2019 \\
x=6\end{array}$ & $\begin{array}{l}2019- \\
2020 \\
x=7\end{array}$ & $\begin{array}{l}2020- \\
2021 \\
x=8\end{array}$ & $\begin{array}{l}2021- \\
2022 \\
x=9\end{array}$ & $\begin{array}{c}2022- \\
2023 \\
x=10\end{array}$ & $\begin{array}{c}2023- \\
2024 \\
x=11\end{array}$ & $\begin{array}{c}2024- \\
2025 \\
x=12\end{array}$ & $\begin{array}{c}2025- \\
2026 \\
x=13\end{array}$ & $\begin{array}{l}2026- \\
2027 \\
x=14\end{array}$ \\
\hline$\%$ Incremen. & 225 & 251.298 & 286.396 & 322.391 & 359.28 & 397.07 & 435.755 & 475.33 & 515.81 & 557.189 \\
\hline $\begin{array}{l}\text { Tariff, 0.6 E£ } \\
\text { (basic) }\end{array}$ & 1.35 & 1.507 & 1.718 & 1.934 & 2.155 & 2.382 & 2.614 & 2.852 & 3.094 & 3.343 \\
\hline $\begin{array}{c}\text { Cost, } 78.493 \\
\mathrm{E} £ / \mathrm{M}\end{array}$ & 240.965 & 268.988 & 306.65 & 345.205 & 384.65 & 425.170 & 471.507 & 509.06 & 552.257 & 596.702 \\
\hline $\begin{array}{c}\text { Costs, } \\
\text { E£/10Y"Old } \\
\text { sys." }\end{array}$ & 2891.58 & 3227.85 & 3679.8 & 4142.46 & 4615.8 & 5102.04 & 5658.08 & 6108.72 & 6627.08 & 7160.42 \\
\hline \multicolumn{11}{|c|}{ Total costs, E£/10Y } \\
\hline \multicolumn{11}{|c|}{ Total costs, $\mathrm{E} £ / 10 \mathrm{Y}$} \\
\hline $\begin{array}{c}\% \text { Total } \\
\text { money-saving, } \\
\mathrm{EE/10Y}\end{array}$ & \multicolumn{10}{|c|}{$29.03 \%,=11,073.055 \mathrm{E} £ / 10$ years } \\
\hline $\begin{array}{c}\text { \% Savings w.r.t } \\
814.08 / \mathrm{Y}\end{array}$ & -24.186 & -15.369 & -3.52 & 8.60 & 21.02 & 33.708 & 48.347 & 60.162 & 73.75 & 87.73 \\
\hline
\end{tabular}
for residential loads "from 2017/2018 to 2026/2027". 


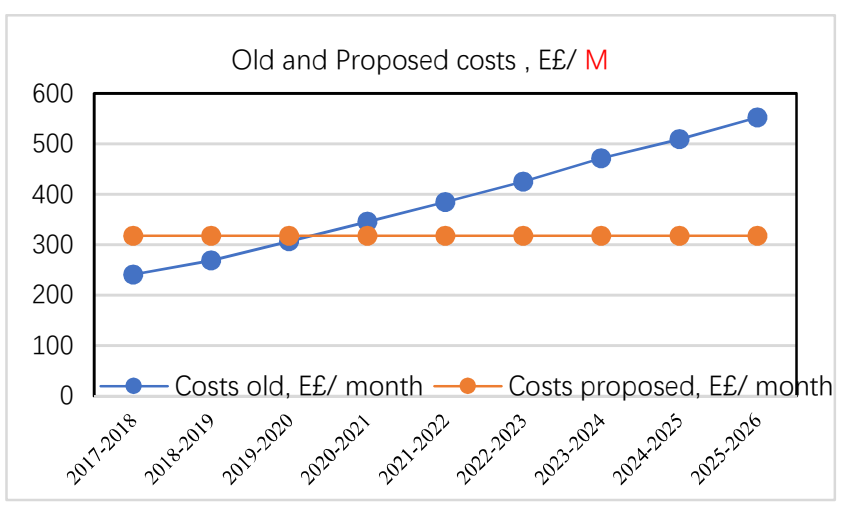

Figure 10. Comparison between the old and proposed hybrid system costs/month for residential "from 2017/2018 to 2026/2027".

Table 7 indicates the comparison between the family consumed energy costs using; the calculations by traditional generation sources and the proposed system through 10 years.

General notes: The total percentage saving money by the proposed system for residential loads is $29.03 \%$ related to the traditional supply (for ten years, Table 7 ), the proposed hybrid system gives the lowest monthly costs instead of the traditional system after the first three years (starts from 2020-2021, Figure 10), and the percentages saving effective values present after the first three years (starts from 2020-2021, Figure 11).

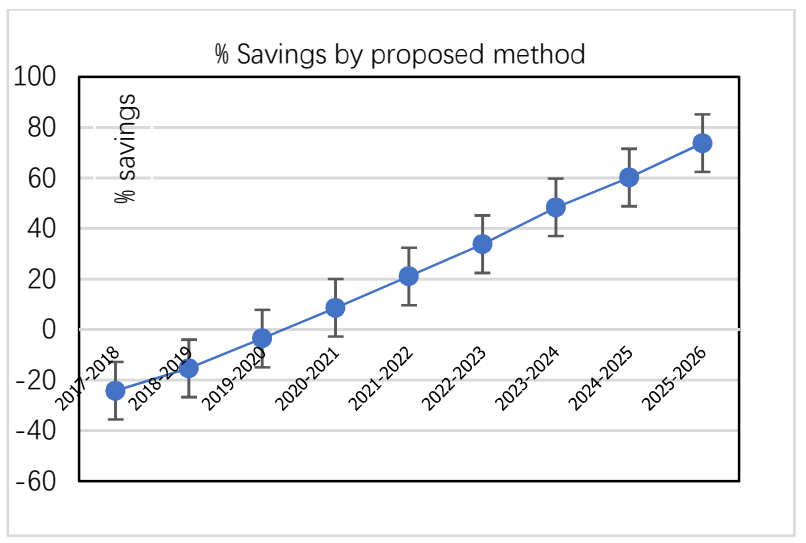

Figure 11. Percentage savings of proposed hybrid system for residential "from year 2017/2018 to year 2026/2027".

Contributions of the Hybrid System

From the above sections:

- $\quad$ The proposed system gives $(27.616-21.66=5.956 \mathrm{kWh} / \mathrm{D})$, which equals $21.567 \%$ of the total residential loads (family with five persons);

- This system will succeed to give the same percentage for all the residential application loads (from Table $8=66,809 \mathrm{GWh}$ ); then

- $\quad$ The given generated energy from the proposed hybrid system is $14408.83 \mathrm{GWh} /$ years) $(0.21567 \times 66089 \mathrm{GWh})$. 
Table 8. Contributions of the proposed hybrid system in various generation/loads types.

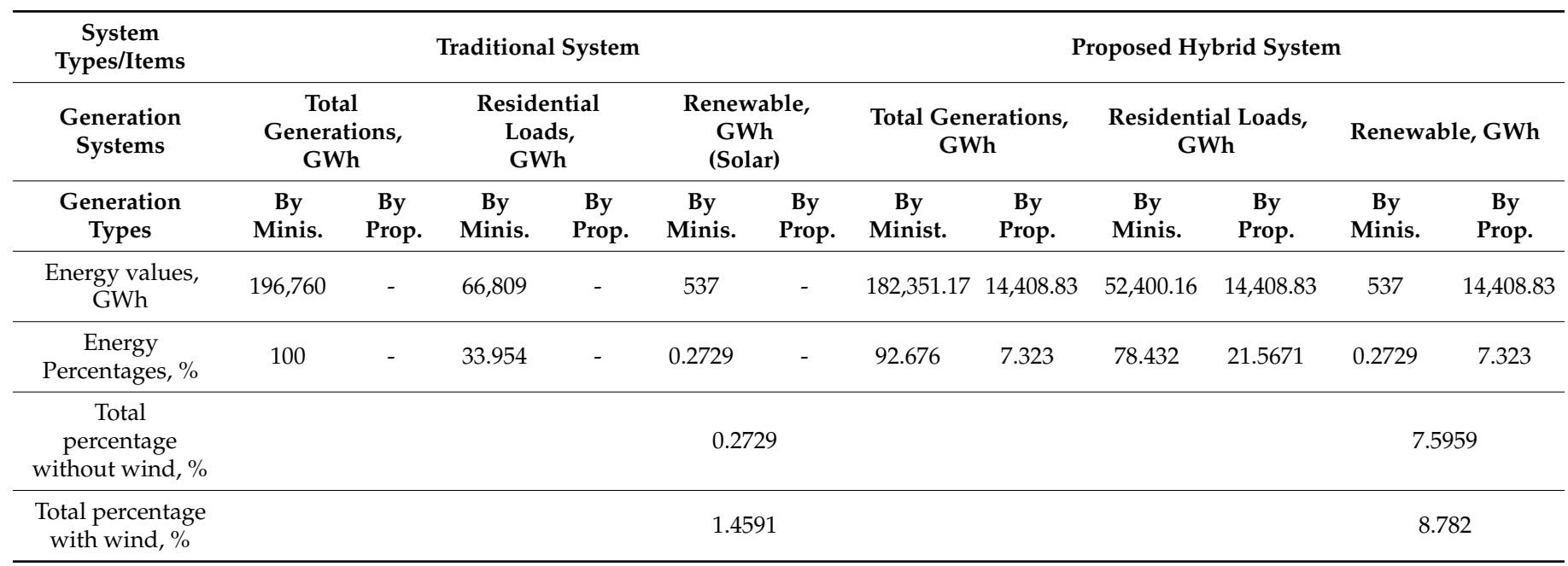

This proposed hybrid system positively affects renewable generation systems, as shown in Figures 10 and 11. Table 8 explains the contributions of the proposed system to increase by effective values of the renewable and total development generation stations in Egypt.

Notices from Tables 7 and 8:

- The renewable ministry systems solar generation contributes only $537 \mathrm{GWh} / \mathrm{Y}$, which equals $0.2729 \%$ of the total developed generated energies;

- The proposed hybrid system will raise the contribution of the renewable (proposed + old solar) to be $14,945.83(537+14,408.83)$, which equals $7.5959 \%$ of the total developed generated energies and leads to reduce the generations of other sources (e.g., steam by the same $7.5959 \%$ values, decreasing in $\mathrm{CO}_{2}$ exhausts);

- The proposed and wind energies will share $8.782 \%(17,279.83 \mathrm{GWh} / \mathrm{Y})$ of the total developed generation energies.

- According to Tables 3 and 7, the proposed hybrid system has two generations systems (Figure 12):

1. Pic-hydraulic system: it contributes by $288.1766 \mathrm{GWh} / \mathrm{Y}(2 \%$ of $14,408.83)$, which has a percentage of $0.14646 \%$ of the total developed generated energies "half the sharing percentage of the traditional solar system", and

2. The solar system contributes by $14,120.653 \mathrm{GWh} / \mathrm{Y}$ ( $98 \%$ of $14,408.83$ ), which has a percentage of 7.1765 from the total developed generated energies (26.29 times the sharing percentage of the traditional solar system of the ministry).

- The generation stations can reduce the total outputs to be $182,351.17 \mathrm{GWh} / \mathrm{Y}$, which is $92.677 \%$ of the old total developed generated energies ( $7.323 \%$ reduction);

- By using the savings from Table 6, the percentage saving money by the hybrid proposed system is $29.03 \%$ related to the traditional system (return to subscribes);

- $\quad$ From Table 8, the proposed system gives $14,408.83 \mathrm{GWh} / \mathrm{Y}$, by using Table 7 for tariff cost from 2017-2027 (ten years) $\mathrm{E} £ / \mathrm{kWh}$ :

1. The total costs of $14,408.83 \mathrm{GWh}$ through 10 years equal $14,408.83 \times(1.35+1.057$ $+1.718+1.934+2.155+2.382+2.614+2.852+3.094+3.343)=330,668.2397$ million $\mathrm{E} £ / 10 Y \mathrm{Ys}(20,666.76$ million $\$$ with rate of change $\$=16 \mathrm{E} £)$

2. The return residential subscribes savings in money through ten years $=330,668.2397$ $\times 0.2903=95,992.9899$ million $\mathrm{E} £ / 10$ Ys (5999.5618 million \$)

- The proposed system will reduce the exhaust from steam stations' $\left(\mathrm{CO}_{2}\right)$ by $7.3 \%$, which leads to a higher clean environment.

- Figure 12 explains the effectiveness of the proposed hybrid system on the renewable generation Egyptian systems (2017-2018). 


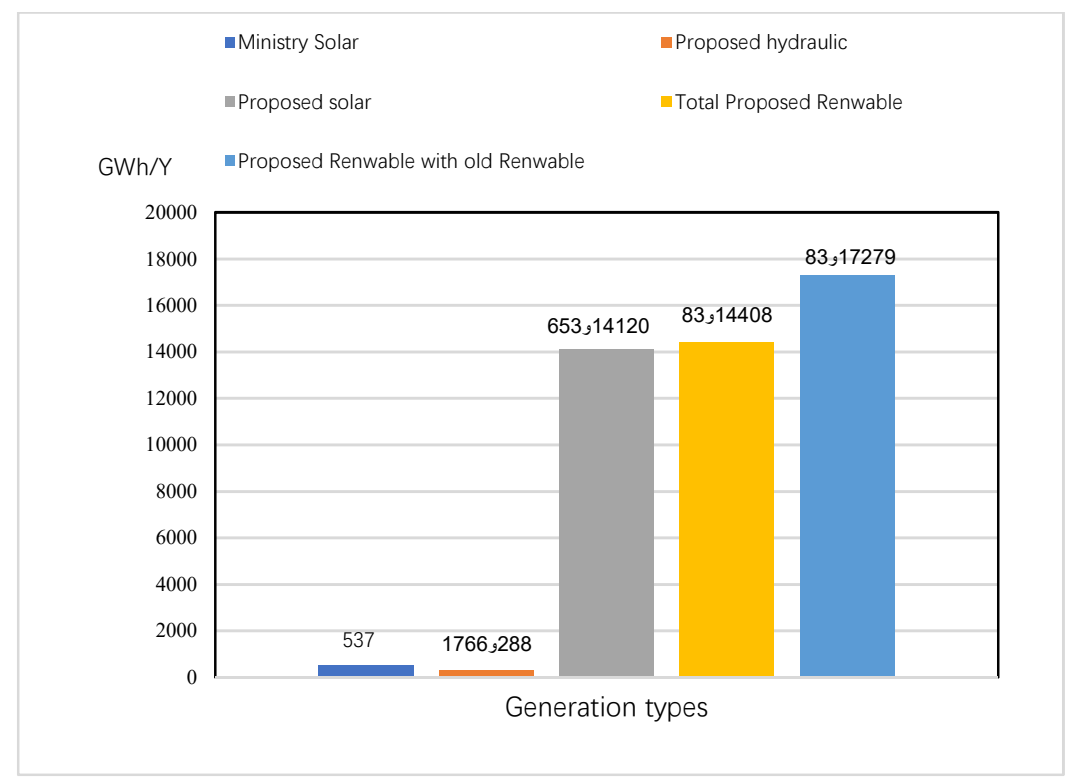

Figure 12. The effectiveness of the proposed hybrid system on the Renewable Egyptian generation systems.

Note that the above residential building generation $(14,408.83)$ by supposing all the buildings are private without public ones. Therefore, if the private will be taken as percentages related to public buildings, the generations and savings-with applied this proposed system-will be shown in Table 9:

Table 9. The generations and saved money with different private residential percentages w.r.t all residential buildings (loads) through 10 years (2017-2027).

\begin{tabular}{|c|c|c|c|}
\hline Percentages \% & Generations, GWh & $\begin{array}{c}\mathrm{Ct}=\text { Costs for } 10 \text { Years } \\
\text { Million } \mathrm{E} f / \$ \times 22.949 \\
(\text { Table } 8)\end{array}$ & $\begin{array}{l}\text { Saving Money Million } \\
\mathrm{E} £ / \$, \mathrm{Ct} \times 0.2903\end{array}$ \\
\hline 10 & 1440.883 & $33,066.82 / 2066.676$ & $9599.298 / 599.956$ \\
\hline 20 & 2881.766 & $66,133.64 / 4133.35$ & $19,198.595 / 1199.91$ \\
\hline 30 & 4322.649 & $99,200.46 / 6200.02$ & $28,797.89 / 1799.868$ \\
\hline 40 & 5763.532 & $132,267.28 / 8266.705$ & $38,397.19 / 2399.8244$ \\
\hline 50 & 7204.415 & $165,334.1 / 10,333.38$ & $47,996.489 / 2999.78$ \\
\hline 60 & 8645.298 & $198,400.9 / 12,400.05$ & $57,595.78 / 3599.73$ \\
\hline 70 & $10,086.181$ & $231,467.74 / 14,466.73$ & $67,195.08 / 4199.69$ \\
\hline 80 & $11,527.06$ & $264,534.56 / 16,533.41$ & $76,794.38 / 4799.64$ \\
\hline 90 & $12,967.947$ & $297,601 / 18,600$ & $86,393.68 / 5399.6$ \\
\hline
\end{tabular}

\section{The Hybrid Generation System}

As discussed in the previous sections, the hybrid system contains two generation systems: Pico-hydraulic and solar (PV). These two generated systems are used with an integrated system to maintain the continuity of supplying voltage to inverter/batteries "Figures 2 and 3". This proposed integrated system has the following advantages: It gives the accepted voltage range to inverter/batteries "continuously" from PV and/Picohydraulic units according to Figure 1, the system must be effective in power generation and money savings for success. It can be used as an emergency power supply in case of shutdown of the ministry power supply directly or from charged batteries, and it is very easy to install, and it uses natural resources (solar and water) to generate high economic and clean energy. 


\section{Applicable Model}

Figure 13 displays the full integrated circuit details used to verify the hybrid generation system operation and efficiency (the model was executed in the electrical power laboratory, faculty of engineering, Kafrelsheikh University). The proposed system model has been tested and checked with various states according to the flowchart in Figure 1. Its operations were accurate and very easy to work, similarly to the methodology displayed in Figure 3.

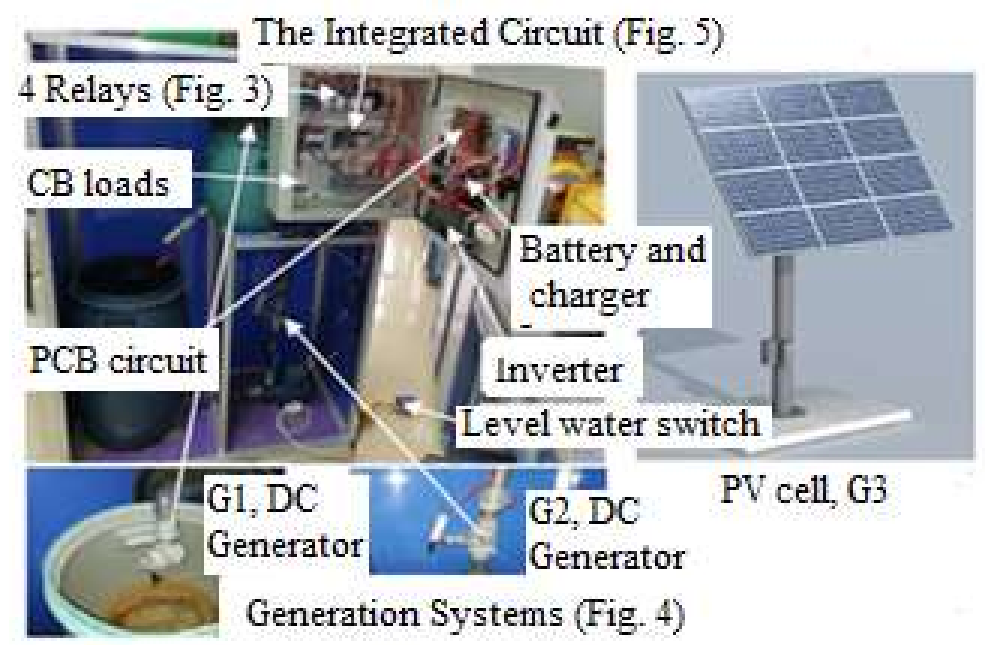

Figure 13. The practical integrated model of the hybrid generation system.

There are actual results from the practical model (Table 10):

Table 10. Different output values from three-generation systems.

\begin{tabular}{|c|c|c|c|c|c|c|c|c|c|c|c|c|}
\hline \multirow{2}{*}{ Cases } & \multicolumn{3}{|c|}{ Pump 1 * } & \multicolumn{3}{|c|}{ Pump 2* } & \multicolumn{3}{|c|}{$\mathbf{P V} * *$} & \multicolumn{3}{|c|}{ Total O/P } \\
\hline & $\mathrm{V}, \mathrm{V}$ & $\begin{array}{l}\text { I, } \\
\text { A }\end{array}$ & $\begin{array}{l}\text { P1, } \\
\text { W }\end{array}$ & $\mathrm{V}, \mathrm{V}$ & $\begin{array}{l}\text { I, } \\
\text { A }\end{array}$ & $\begin{array}{l}\text { P2, } \\
\text { W }\end{array}$ & $\mathbf{V}, \mathbf{V}$ & $\begin{array}{l}\text { I, } \\
\text { A }\end{array}$ & $\begin{array}{l}\text { P3, } \\
\text { W }\end{array}$ & $\mathrm{V}, \mathrm{V}$ & $\begin{array}{l}\text { I, } \\
\text { A }\end{array}$ & $\begin{array}{l}\text { PT } \\
W\end{array}$ \\
\hline 1 & 12 & 0.83 & 10 & - & - & - & - & - & - & 12 & 0.83 & 10 \\
\hline 2 & - & - & - & 10 & 0.8 & 8 & - & - & - & 10 & 0.8 & 8 \\
\hline 3 & - & - & - & - & - & - & 12 & 8.3 & 100 & 12 & 8.3 & 100 \\
\hline 4 & 12 & 0.83 & 10 & - & - & - & 12 & 8.3 & 100 & 12 & 9.1 & 109.95 \\
\hline 5 & - & - & - & 10 & 0.8 & 8 & 12 & 8.3 & 100 & 11 & 9.1 & 108 \\
\hline 6 & 12 & 0.83 & 10 & 5.6 & 0.44 & 2.46 & - & - & - & 12 & 0.83 & 10 \\
\hline 7 & 8 & 0.66 & 5.28 & 4.2 & 0.336 & 1.4 & - & - & - & 12.2 & 0.996 & 6.6 \\
\hline
\end{tabular}

Note that: This proposed model has been tested with two DC generators (10 W each) to verify the success of operations.

\section{Conclusions and Policy Implications}

This study numerically investigates hybrid Pico-hydraulic and PV systems using the proposed model (integrated system). The proposed hybrid system discusses the renewable energy challenge, the actual existing data for the world and Egypt as an application case study, the generation and consumption according to verified references, and the cost analysis of the proposed system related to the traditional generation systems. The proposed hybrid system has much potential (advantages); simple, reliable, efficient and improving the operational performance of renewable energy systems. Furthermore, the mathematical equations, calculations, discussions, and practical models were drawn (positive impacts):

- Continuous supply allowable charging voltages to inverter/batteries by this intelligent circuit (whether the outputs voltages from water/solar in its ranges/levels or not).

- Emergency supply system home loads can be supplied. 
- Increase the contribution of renewable energy by the solar system from $0.273 \%$ to $7.595 \%$ of the total different installed generation stations in Egypt.

- Saves a lot of money for residential users (subscribers); each family can save $11,073 \mathrm{E} £ / 10 \mathrm{Y}$ (\$296.06) through service lifetimes of application of this proposed system related to supplying the same loads by the government system.

- On a large scale, according to Table 9, the savings in money in the residential subscriptions sector (through ten years) ranged from 9599.298 million $\mathrm{E} £ / 10 \mathrm{Ys}$ (lowest percentage, $10 \%$ ) up to $86,393.68$ million $E £ / 10 Y s=5399.6$ million $\$$ (percentage $90 \%$ ).

- Uses the daily human usage water in the home to give $288.1766 \mathrm{GWh} / \mathrm{Y}$ ( $2 \%$ of $14,408.83$ ), which has a percentage of $0.14646 \%$ of the total developed generated energies (half the sharing percentage of the total updated traditional solar system in Egypt through 2017-2018).

- Uses solar energy (nature resource) to give $14,120.653 \mathrm{GWh} / \mathrm{Y}$ ( $98 \%$ of $14,408.83$ ), which has a percentage of $7.1765 \%$ of the total developed generated energies (26.29 times the sharing percentage of the traditional solar system in Egypt through 2017-2018).

- Help the Egyptian electrical ministry to reduce the energy outputs from its generation stations to be $182,351.17 \mathrm{GWh} / \mathrm{Y}$. This reduction is $7.323 \%$ of the total developed supplied energy, which increases the service lifetime of ministry generation stations (decreasing their maximum loads) and gives the government a chance to install new projects to use this extra generation energy.

- Increase the system power quality.

- For environmental impact, it reduces the exhaust from steam stations' $\left(\mathrm{CO}_{2}\right.$ (by $7.3 \%$ ), which equals the added by the proposed system), which leads to a higher clean environment.

- Some of the houses are individuals (e.g., Villa), which has its green land around it. This green land takes about half the quantity of water house; this means the generation of picohydraulic may share with another percentage value added to the previous percentage.

- It can be applied to all residential and commercial buildings to save users and the government more.

But, there are limitations on the application of this proposed system: needs the source of hydraulic system (water tank) and solar sources to give all the above benefits. The output voltages and energy are still in low ranges, with interest on the cost and maintenance fee for the pico-hydro power generator and the decline of photovoltaic cell performance. There is a reduction in the saved by this study may be limited to a very percentage (maybe less than $0.05 \%$ from $7.3 \%$ ). In addition, there is no support by governments to apply this model.

In future research, authors will try to overcome these drawbacks by:

- This proposed study must be supported by governments by giving bonuses on the bill, and reducing the cost by not applying tax and customs on the products used in the application to consumers in a residential and commercial building, and

- $\quad$ Try to apply this model for large scales (e.g., irrigation projects).

Author Contributions: Conceptualization, F.F.S.; methodology, F.F.S.; software, F.F.S.; Validation, F.F.S., A.A. and I.B.M.T.; formal analysis, F.F.S.; investigation, I.B.M.T.; resources, F.F.S.; data curation, F.F.S.; writing—original draft preparation, F.F.S.; writing—review and editing, A.A.; visualization, F.F.S.; supervision, F.F.S.; project administration, A.A. All authors have read and agreed to the published version of the manuscript.

Funding: Ibrahim B. M. Taha is the author who received the financial grant from Taif University Researchers Supporting Project (Number TURSP-2020/61), Taif University, Taif, Saudi Arabia.

Acknowledgments: The authors acknowledge the financial support received from Taif University Researchers Supporting Project (Number TURSP-2020/61), Taif University, Taif, Saudi Arabia.

Conflicts of Interest: The authors declare no conflict of interest. 


\section{Nomenclature}

\begin{tabular}{|c|c|}
\hline \multicolumn{2}{|c|}{ Abbreviations } \\
\hline $\mathrm{ACHE}$ & Adaptive control of the home environment \\
\hline PV. & Photo-voltaic \\
\hline PVT & Photovoltaic thermal \\
\hline PVT-CR & Photothermic-radiative cooling \\
\hline CPV & Concentrator Photovoltaic \\
\hline $\mathrm{RE}$ & Renewable Energy \\
\hline \multicolumn{2}{|l|}{ Symbols } \\
\hline$P_{m}$ & Theoretical mechanical horsepower \\
\hline Q & The flow rate in cubic feet per second \\
\hline $\mathrm{V}$ & The velocity of flow, $\mathrm{m} / \mathrm{s}$ \\
\hline $\mathrm{P}$ & Pressure, $\mathrm{N} / \mathrm{m}^{2}$ \\
\hline$P$ & The density of water, $\mathrm{kg} / \mathrm{m}^{3}$ \\
\hline$P_{t}$ & The output from the turbine, $\mathrm{W}$ \\
\hline Q & The flow rate in the pipe $\left(\mathrm{m}^{3} / \mathrm{s}\right)$ \\
\hline$\widetilde{G}$ & Acceleration of gravity $\left(\right.$ for water $\left.=9.81 \mathrm{~m} / \mathrm{s}^{2}\right)$ \\
\hline $\mathrm{H}_{\mathrm{n}}$ & The net height, $\mathrm{m}$ \\
\hline $\mathrm{H}_{\mathrm{g}}$ & Gross vertical head, $\mathrm{m}$ \\
\hline $\mathrm{H}_{\mathrm{lo}}$ & Head loss, m \\
\hline$\eta_{\mathrm{t}}$ & Turbine efficiency \\
\hline$P_{\text {op }}$ & The net output from the generator, $\mathrm{W}$ \\
\hline$\eta_{\mathrm{g}}$ & Generator efficiency \\
\hline $\mathrm{N}_{\mathrm{S}}$ & The specific speed of the turbine, rpm \\
\hline $\mathrm{N}_{\mathrm{t}}$ & Turbine's rotation speed (rpm) \\
\hline $\mathrm{P}_{\mathrm{p}}$ & Daily consumed power for each family home person is denoted by, KWh \\
\hline $\mathrm{N}$ & Number of family persons \\
\hline $\mathrm{P}_{\mathrm{T}}$ & The actual total family persons daily consumed power, KWh \\
\hline$Q_{p}$ & Consumed water/family person, $\mathrm{m}^{3}$ \\
\hline $\mathrm{Q}_{\mathrm{T}}$ & Total consumed water for all family persons, $\mathrm{m}^{3}$ \\
\hline$P_{\mathrm{ec}}$ & $\begin{array}{l}\text { Total consumed power for all family persons must be Limited to economic } \\
\text { value, and it is denoted by, KWh }\end{array}$ \\
\hline $\mathrm{P}_{\mathrm{w}}$ & The pressure, psi \\
\hline $\mathrm{TDH}$ & Total dynamic head, feet \\
\hline Gpm & Pumping rate in gallons per minute \\
\hline Whp & Gpm \\
\hline$P_{S}$ & Additional solar generation power, $\mathrm{KW} \mathrm{h}$ \\
\hline $\mathrm{E} £$ & Egyptian pound \\
\hline
\end{tabular}

\section{References}

1. Mehta, V.K.; Mehta, R. Principles of Power Systems; Chand: New Delhi, India, 2005; p. 15.

2. Fang, Y.; Wei, W.; Mei, S.; Chen, L.; Zhang, X.; Huang, S. Promoting electric vehicle charging infrastructure considering policy incentives and user preferences: An evolutionary game model in a small-world network. J. Clean. Prod. 2020, $258,120753$. [CrossRef]

3. Pérez-Lombard, L.; Ortiz, J.; Pout, C. A review on buildings energy consumption information. Energy Build. 2008, 40, 394-398. [CrossRef]

4. Zazzini, P.; Romano, A.; Di Lorenzo, A.; Portaluri, V.; Di Crescenzo, A. Experimental Analysis of the Performance of Light Shelves in Different Geometrical Configurations Through the Scale Model Approach. J. Daylighting 2020, 7, 37-56. [CrossRef]

5. Ricquebourg, V.; Menga, D.; Durand, D.; Marhic, B.; Delahoche, L.; Loge, C. The Smart Home Concept: Our immediate future. In Proceedings of the 2006 1ST IEEE International Conference on E-Learning in Industrial Electronics, Hammamet, Tunisia, 18-20 December 2006; pp. 23-28.

6. Sripan, M.; Lin, X.; Petchlorlean, P.; Ketcham, M. Research and thinking of smart home technology. In Proceedings of the International Conference on Systems and Electronic Engineering (ICSEE'2012), Phuket, Thailand, 18-19 November 2012; pp. 61-64.

7. Alam, M.R.; Reaz, M.B.I.; Ali, M.A.M. A Review of Smart Homes—Past, Present, and Future. IEEE Trans. Syst. Man Cybern. Part C 2012, 42, 1190-1203. [CrossRef] 
8. Rehman, A.U.; Wadud, Z.; Elavarasan, R.M.; Hafeez, G.; Khan, I.; Shafiq, Z.; Alhelou, H.H. An Optimal Power Usage Scheduling in Smart Grid Integrated With Renewable Energy Sources for Energy Management. IEEE Access 2021, 9, 84619-84638. [CrossRef]

9. The Lighting Handbook; Zumtobel Lighting GmbH: Dornbirn, Austria, 2016. Available online: https://www.zumtobel.com/PDB /teaser/SV /Lichthandbuch.pdf (accessed on 10 September 2021).

10. Selim, F.; Abdelwanis, M.I. Advance low-cost smart power savings system for public buildings. In Proceedings of the 11th ICEENG Conference, Cairo, Egypt, 3-5 April 2018. [CrossRef]

11. Li, Z.; Li, J.; Li, X.; Yang, Y.; Xiao, J.; Xu, B. Design of Office Intelligent Lighting System Based on Arduino. Procedia Comput. Sci. 2020, 166, 134-138. [CrossRef]

12. Ergüzel, A.T. A study on the implementation of dimmable street lighting according to vehicle traffic density. Optik 2019, 184, 142-152. [CrossRef]

13. Li, D.H.W.; Li, S.; Chen, W. Estimating the switching frequency and energy saving for daylight-linked lighting on-off controls. Energy Procedia 2019, 158, 2878-2883. [CrossRef]

14. Chraibi, S.; Creemers, P.; Rosenkötter, C.; Van Loenen, E.; Aries, M.; Rosemann, A. Dimming strategies for open office lighting: User experience and acceptance. Light. Res. Technol. 2019, 51, 513-529. [CrossRef]

15. Wagiman, K.R.; Abdullah, M.N.; Hassan, M.Y.; Radzi, N.H.M.; Abu Bakar, A.H.; Kwang, T.C. Lighting system control techniques in commercial buildings: Current trends and future directions. J. Build. Eng. 2020, 31, 101342. [CrossRef]

16. Elavarasan, R.M.; Shafiullah, G.; Padmanaban, S.; Kumar, N.M.; Annam, A.; Vetrichelvan, A.M.; Mihet-Popa, L.; Holm-Nielsen, J.B. A Comprehensive Review on Renewable Energy Development, Challenges, and Policies of Leading Indian States With an International Perspective. IEEE Access 2020, 8, 74432-74457. [CrossRef]

17. Elavarasan, R.; Shafiullah, G.; Kumar, N.M.; Padmanaban, S. A State-of-the-Art Review on the Drive of Renewables in Gujarat, State of India: Present Situation, Barriers and Future Initiatives. Energies 2019, 13, 40. [CrossRef]

18. Hassan, T.-U.; Abbassi, R.; Jerbi, H.; Mehmood, K.; Tahir, M.; Cheema, K.; Elavarasan, R.; Ali, F.; Khan, I. A Novel Algorithm for MPPT of an Isolated PV System Using Push Pull Converter with Fuzzy Logic Controller. Energies 2020, 13, 4007. [CrossRef]

19. Kiani, A.T.; Nadeem, M.F.; Ahmed, A.; Khan, I.; Elavarasan, R.M.; Das, N. Optimal PV Parameter Estimation via Double Exponential Function-Based Dynamic Inertia Weight Particle Swarm Optimization. Energies 2020, 13, 4037. [CrossRef]

20. Kumar, S.; Sarita, K.; Vardhan, A.; Elavarasan, R.; Saket, R.; Das, N. Reliability Assessment of Wind-Solar Pv Integrated Distribution System Using Electrical Loss Minimization Technique. Energies 2020, 13, 5631. [CrossRef]

21. Elavarasan, R.M.; Leoponraj, S.; Dheeraj, A.; Irfan, M.; Sundar, G.G.; Mahesh, G. PV-Diesel-Hydrogen fuel cell based grid connected configurations for an institutional building using BWM framework and cost optimization algorithm. Sustain. Energy Technol. Assess. 2021, 43, 100934. [CrossRef]

22. Shafiullah, G.; Masola, T.; Samu, R.; Elavarasan, R.M.; Begum, S.; Subramaniam, U.; Romlie, M.F.; Chowdhury, M.; Arif, M.T. Prospects of Hybrid Renewable Energy-Based Power System: A Case Study, Post Analysis of Chipendeke Micro-Hydro, Zimbabwe. IEEE Access 2021, 9, 73433-73452. [CrossRef]

23. Al-Sakaf, O.H. Application possibilities of solar thermal power plants in Arab countries. Renew. Energy 1998, 14, 1-9. [CrossRef]

24. Egypt Consumer Protection Agency. Available online: http:/ /www.egyptera.org/ (accessed on 10 September 2021).

25. Soliman, K.H. Rainfall over Egypt. Q. J. R. Meteorol. Soc. 1953, 79, 389-397. [CrossRef]

26. WMO. The Climatological Norm for the Period 1961-1990 WMO/OMM. No. 847. Available online: https://library.wmo.int/in dex.php?lvl=categ_see\&id=10986 (accessed on 10 September 2021).

27. Shaltout, M.A. Egyptian solar radiation atlas. In New and Renewable Authority; Ministry of Electricity and Energy: Cairo, Egypt, 1991. Available online: http:/ / www.worldcat.org/title/egyptian-solar-radiation-atlas/oclc/25011751 (accessed on 10 September 2021).

28. Tadros, M. Uses of sunshine duration to estimate the global solar radiation over eight meteorological stations in Egypt. Renew. Energy 2000, 21, 231-246. [CrossRef]

29. Robaa, S. Evaluation of sunshine duration from cloud data in Egypt. Energy 2008, 33, 785-795. [CrossRef]

30. Angstrom, A. Solar and terrestrial radiation. Report to the international commission for solar research on actinometric investigations of solar and atmospheric radiation. Q. J. R. Meteorol. Soc. 1924, 50, 121-126. [CrossRef]

31. Liu, B.Y.; Jordan, R.C. The interrelationship and characteristic distribution of direct, diffuse and total solar radiation. Sol. Energy 1960, 4, 1-19. [CrossRef]

32. Kabeel, A.; Abdelgaied, M.; Sathyamurthy, R. A comprehensive investigation of the optimization cooling technique for improving the performance of PV module with reflectors under Egyptian conditions. Sol. Energy 2019, 186, 257-263. [CrossRef]

33. Elkholy, A. Harmonics assessment and mathematical modeling of power quality parameters for low voltage grid connected photovoltaic systems. Sol. Energy 2019, 183, 315-326. [CrossRef]

34. Hemeida, A.; El-Ahmar, M.; El-Sayed, A.; Hasanien, H.M.; Alkhalaf, S.; Esmail, M.; Senjyu, T. Optimum design of hybrid wind/PV energy system for remote area. Ain Shams Eng. J. 2020, 11, 11-23. [CrossRef]

35. Swief, R.; El-Amary, N.H. Optimal probabilistic reliable hybrid allocation for system reconfiguration applying WT/PV and reclosures. Ain Shams Eng. J. 2020, 11, 109-118. [CrossRef]

36. Bureau of Reclamation. Hydroelectric Power; US Department of Interior. Available online: https://www.usbr.gov/power/ (accessed on 10 September 2021). 
37. Al-juboori, S.S. Hydroelectric Power. Energy Science \& Technology: Opportunities and Challenges. Available online: https://www.re searchgate.net/publication/315493188 (accessed on 10 September 2021).

38. Singh, V.K.; Chauhan, N.S.; Kushwaha, D. An overview of hydroelectric power plant. ISST J. Mech. Eng. 2015, 6, 59-62.

39. Lajqi, S.; Lajqi, N.; Hamidi, B. Design and construction of mini hydropower plant with propeller turbine. Int. J. Contemp. Energy 2016, 2, 1-13. [CrossRef]

40. Li, J.; Saw, M.M.M.; Chen, S.; Yu, H. Short-Term Optimal Operation of Baluchaung II Hydropower Plant in Myanmar. Water 2020, 12, 504. [CrossRef]

41. Uddin, W.; Ayesha, Z.K.; Haider, A.; Khan, B.; Islam, S.U.; Ishfaq, M.; Khan, I.; Adil, M.; Kim, H.J. Current and future prospects of small hydro power in Pakistan: A survey. Energy Strat. Rev. 2019, 24, 166-177. [CrossRef]

42. Hatata, A.; El-Saadawi, M.; Saad, S. A feasibility study of small hydro power for selected locations in Egypt. Energy Strat. Rev. 2019, 24, 300-313. [CrossRef]

43. Ribeiro, A.C.A. Mathematical Problems of Hydroelectric Power Stations Management. Ph.D Thesis, University of Porto, Porto, Portugal, 2014.

44. Moniruzzaman, E. Hydroelectric Power Generation System. Master Thesis, Dhaka University of Engineering \& Technology, Gazipur City, Bangladesh, 2019. Available online: https:/ / www.researchgate.net/publication/332170877 (accessed on 8 September 2021).

45. Hydro Electric Power (Hydel Power). Available online: https://www.studentenergy.org/topics/hydro-power (accessed on 8 September 2021).

46. Anaza, S.O.; Abdulazeez, M.S.; Yisah, Y.A.; Yusuf, Y.O.; Salawu, B.U.; Momoh, S.U. Micro hydroelectric energy generation- an overview. Am. J. Eng. Res. 2017, 6, 5-12.

47. How Much Hydropower Power Could I Generate from a Hydro Turbine? Renewable: The Hydro and Wind Co. Available online: https://www.renewablesfirst.co.uk/hydropower/hydropower-learning-centre/how-much-power-could-i-generate-f rom-a-hydro-turbine/ (accessed on 1 September 2021).

48. Aqel, M.O.A.; Issa, A.; Qasem, E.; El-Khatib, W. Hydroelectric Generation from Water Pipelines of Buildings. In Proceedings of the 2018 International Conference on Promising Electronic Technologies (ICPET), Deir El-Balah, Palestine, 3-4 October 2018; pp. 63-68.

49. Kougias, I.; Aggidis, G.; Avellan, F.; Deniz, S.; Lundin, U.; Moro, A.; Muntean, S.; Novara, D.; Pérez-Díaz, J.I.; Quaranta, E.; et al. Analysis of emerging technologies in the hydropower sector. Renew. Sustain. Energy Rev. 2019, 113, 109257. [CrossRef]

50. Raja, A.K.; Srivastava, A.P.; Dwivedi, M. Power Plant Engineering; New Age International Ltd.: Delhi, India, 2006.

51. Abdulkareem, M.A. Hydro-water power plant. Power Plant Lecture Notes; Al-Mustansiriya University. Chapter 7, 2017. Available online: https:/ / www.researchgate.net/publication/304396387 (accessed on 1 September 2021).

52. Brekke, H. Hydraulic Turbines Design, Erection and Operation; Norwegian University of Science and Technology: Trondheim, Norway, 2001.

53. Gabriel, C.D.; Odhiambo, P.; Odhach, J. Designing a Small Hydro Power Plant Capable of Producing 10 MW of Electricity at Webuye Along River Nzoia. First Year Project, Nairobi University. 2015. Available online: https:/ /pdfcoffee.com/design-of-a-sm all-hydro-power-plantpdf-pdf-free.html (accessed on 1 August 2021).

54. Zaman, A.; Khan, T. Design of a water wheel for a low head micro hydro power system. J. Basic Sci. Technol. 2012, 1, 1-6.

55. Abdel-Aziz, T.M.; Salam, N.M.A. Characteristic Equations for Hydropower Stations of Main Barrages in Egypt. In Proceedings of the Eleventh International Water Technology Conference IWTC11, Sharm El-Sheikh, Egypt, 1 January 2007. Available online: https://www.researchgate.net/publication/270750891_CHARACTERISTIC_EQUATIONS_FOR_HYDROPOWER_S TATIONS_OF_MAIN_BARRAGES_IN_EGYPT (accessed on 1 August 2021).

56. Module 5 Hydropower Engineering. Version 2 CE IIT, Kharagpur. Available online: https:/ /www.yumpu.com/en/document/vi ew /15174084/module-5-nptel (accessed on 1 August 2021).

57. Pali, B.S.; Vadhera, S. An Innovative Continuous Power Generation System Comprising of Wind Energy Along With PumpedHydro Storage and Open Well. IEEE Trans. Sustain. Energy 2020, 11, 145-153. [CrossRef]

58. Zainuddin, H.; Yahaya, M.S.; Lazi, J.M.; Basar, M.M.F.; Ibrahim, Z. Design and development of pico-hydro generation system for energy storage using consuming water distributed to houses. Int. J. Electr. Comput. Energetic Electron. Commun. Eng. 2009, 3, 1928-1932. Available online: https://www.researchgate.net/publication/280688181 (accessed on 1 August 2021).

59. Fipps, G. Calculating Horsepower Requirements and Sizing Irrigation Supply Pipelines; Texas Agricultural Extension Service, Texas A\&M University System: College Station, TX, USA, 2019. Available online: https://cdn-ext.agnet.tamu.edu/wp-content/upload s/2019/03/EB-6011-calculating-horsepower-requirements-and-sizing-supply-pipelines-for-irrigation.pdf (accessed on 11 June 2021).

60. Li, P.; Zhou, K.; Lu, X.; Yang, S. A hybrid deep learning model for short-term PV power forecasting. Appl. Energy 2020, 259, 114216. [CrossRef]

61. Shen, L.; Li, Z.; Ma, T. Analysis of the power loss and quantification of the energy distribution in PV module. Appl. Energy 2020, 260, 114333. [CrossRef]

62. Jordehi, A.R. Enhanced leader particle swarm optimisation (ELPSO): An efficient algorithm for parameter estimation of photovoltaic (PV) cells and modules. Sol. Energy 2018, 159, 78-87. [CrossRef] 
63. Chen, Y.; Sun, Y.; Meng, Z. An improved explicit double-diode model of solar cells: Fitness verification and parameter extraction. Energy Convers. Manag. 2018, 169, 345-358. [CrossRef]

64. Rezk, H.; Fathy, A. A novel optimal parameters identification of triple-junction solar cell based on a recently meta-heuristic water cycle algorithm. Sol. Energy 2017, 157, 778-791. [CrossRef]

65. Mostafa, M.R.; Saad, N.H.; El-Sattar, A.A. Tracking the maximum power point of PV array by sliding mode control method. Ain Shams Eng. J. 2020, 11, 119-131. [CrossRef]

66. Rahmanian, S.; Hamzavi, A. Effects of pump power on performance analysis of photovoltaic thermal system using CNT nanofluid. Sol. Energy 2020, 201, 787-797. [CrossRef]

67. Esfe, M.H.; Kamyab, M.H.; Valadkhani, M. Application of nanofluids and fluids in photovoltaic thermal system: An updated review. Sol. Energy 2020, 199, 796-818. [CrossRef]

68. Müller, J.; Trutnevyte, E. Spatial projections of solar PV installations at subnational level: Accuracy testing of regression models. Appl. Energy 2020, 265, 114747. [CrossRef]

69. Hu, M.; Zhao, B.; Ao, X.; Ren, X.; Cao, J.; Wang, Q.; Su, Y.; Pei, G. Performance assessment of a trifunctional system integrating solar PV, solar thermal, and radiative sky cooling. Appl. Energy 2020, 260, 114167. [CrossRef]

70. Awad, M.; Radwan, A.; Abdelrehim, O.; Emam, M.; Shmroukh, A.N.; Ahmed, M. Performance evaluation of concentrator photovoltaic systems integrated with a new jet impingement-microchannel heat sink and heat spreader. Sol. Energy 2020, 199, 852-863. [CrossRef]

71. Stainsby, W.; Zimmerle, D.; Duggan, G.P. A method to estimate residential PV generation from net-metered load data and system install date. Appl. Energy 2020, 267, 114895. [CrossRef]

72. The Annual Report for Consumed Energy in Egypt. Available online: http://www.moee.gov.eg/test_new/ST_consumption.aspx (accessed on 1 August 2021).

73. Egypt Electric Power Tariff. Available online: https://www.eehc.gov.eg/eehcportal/eng/YearlyReport/finalEnglish.pdf or http:/ / egyptera.org/ar/Tarrif2017.aspx\# (accessed on 1 August 2021).

74. The Consumed Water in Egypt. Available online: https: / / www.shorouknews.com/news / view.aspx?cdate=23092018\&id=76375 89e-6c70-4060-acf8-ad420dd7a838 (accessed on 1 August 2021).

75. The Relation between Psi and Bar. Available online: https://www.differencebetween.com/difference-between-psi-and-bar (accessed on 13 June 2021).

76. Psi to Bar Conversion. Available online: https:/ / www.asknumbers.com/psi-to-bar.aspx (accessed on 13 June 2021 ).

77. The Turbine-Generator Efficiency. Available online: http://www.orient-hose.com/project/pvc-garden-hose/?gclid=CjwKCAi A66_xBRBhEiwAhrMuLa3rkrJIiXuE8zZMG-fQ09yMuIWopQ0VXZ29HjyD_HzGzvafcKd1YBoCAAgQAvD_BwE (accessed on 13 June 2021).

78. The Conversion between Gallon to Cubic Metre. Available online: https://www.convertunits.com/from/gallons+per+minute/t $\mathrm{o} /$ cubic+meters+per+day (accessed on 15 June 2021).

79. The Prices of Inverters. Available online: https://www.made-in-china.com/products-search/hot-china-products/DC_To_AC_ Inverter.html (accessed on 18 June 2021).

80. The Prices of PV. Available online: https:/ / www.google.com/search?q=solar+ell+price+lis+dollar\&tbm=isch\&ved=2ahUKEwj XoYzdt9voAhUTO-wKHTjeBjEQ2-cCegQIABAA\&oq=solar+ell+price+lis+dollar\&gs_lcp=CgNpbWcQAzoECCMQJzoCCAA 6BAgAEEM6BAgAEB46BAgAEBM6CAgAEAgQHhATUIWCAlidzwJgxtICaABwAHgAgAHOAogBrC2SAQgwLjcuMTcuM pgBAKABAaoBC2d3cy13aXotaW1n\&sclient=img\&ei=JyGPXpfyFpP2sAe4vJuIAw\&bih=708\&biw=1440\&rlz=1C1SQJL_enSA8 67SA868\&safe=strict\#imgrc=n6wyL-JxQHwOjM (accessed on 19 June 2021).

81. PV Products and Prices. Available online: https:/ / www.amazon.com/SAVEMORE4U18/b/ref=bl_dp_s_web_17348805011?ie=U TF8\&node=17348805011\&field-lbr_brands_browse-bin=SAVEMORE4U18 (accessed on 19 June 2021).

82. DC Generators Types and Prices. Available online: https://www.alibaba.com/product-detail/Germany-Free-Ship-L ithium-ion-20Ah_62003155567.html?spm=a2700.pcdrm.normalList.10.2e53rTdbrTdbeu\&s=p\&fullFirstScreen=truehttps: / / www.qoo10.sg/g/544768068?source=ig102cc4da3c06559e5d1c405d9cf0283pte7p3f-000M00h0\&jaehuid=2026298010 (accessed on 19 June 2021).

83. Walubita, L.F.; Djebou, D.C.S.; Faruk, A.N.M.; Lee, S.I.; Dessouky, S.; Hu, X. Prospective of Societal and Environmental Benefits of Piezoelectric Technology in Road Energy Harvesting. Sustainability 2018, 10, 383. [CrossRef] 